\title{
ERDŐTÁRSULÁSOK ÉS FAFAJAIK ÁTRENDEZŐDÉSI LEHETŐSÉGEI A VÁLTOZÓ KLÍMÁBAN
}

\author{
Bartha Dénes ${ }^{1}$, Berki Imre2, Lengyel Attila ${ }^{3,4}$, Rasztovits Ervin ${ }^{5}$, \\ Tiborcz Viktor ${ }^{1}$ és Zagyvai Gergely ${ }^{1}$ \\ 1 Soproni Egyetem, Növénytani és Természetvédelmi Intézet \\ 2 Soproni Egyetem, Környezet- és Földtudományi Intézet \\ ${ }^{3}$ MTA Ökológiai Kutatóközpont, Ökológiai és Botanikai Intézet \\ 4 Wroclawi Egyetem, Vegetációökológiai Tanszék (Lengyelország) \\ 5 NAIK, Erdészeti Tudományos Intézet
}

\begin{abstract}
Kivonat
Kutatásunk sokrétủ megközelitést tükröz. Honos fafajaink becsült reakciói alapján elemeztük őshonos fafajú erdőtársulásaink várható átrendeződését. Az elméleti becsléseket összedolgoztuk az újulatra és mortalitásra vonatkozó terepi vizsgálatok eredményeivel. Potenciális, invázióbiológiai szempontból alacsony kockázatú cserefafajokat kerestünk a várhatóan visszaszoruló fafajaink esetleges helyettesitésére. A honos és inváziós fafafajok esetében országos adatokon nyugvó, cserefafajok esetében európai léptékủ modellezéssel is becsültük a fajok potenciális és prognosztikus elterjedését. Potenciális természetes erdőtársulás (PTE) adatbázist építettünk fel az ország erdőterületeire az Országos Erdőállomány Adattár alapján, a jelenre és jövőre vonatkozóan egyaránt. Eredményeink alapján az erdö- és erdőssztyep-társulások esetében egyaránt a magas összetételi (elegyesség) és szerkezeti diverzitás (gyepekkel, cserjésekkel mozaikoló állományok) jelenthet nagyobb alkalmazkodóképességet. A kiválasztott tájidegen fafajok alkalmazására csak az új körülmények között is vitális, őshonos taxonok és az általuk alkotott (akár újszerü) társulások által nyújtott lehetőségek kimerülését követően kerülhet sor.
\end{abstract}

Kulcsszavak: klímaváltozás, fafajösszetétel, potenciális elterjedés, cserefafajok, potenciális természetes erdőtársulás.

\section{ESTIMATED SHIFTS OF FOREST COMMUNITIES AND TREE SPECIES DURING CHANGING CLIMATE}

\begin{abstract}
Our study reflects a multiple approach. On the basis of native tree species estimated response we analyzed the probable rearrangement of our native forest communities. Theoretical estimations were synthetize with result of field work tree mortality and regrowth examination. From the point of view of potential invasion biology, low risk tree species were chose for possible substitution of our native species. In case of native and invasive species country scale databases, in case of substitute tree species european scale were used for predict future potential distribution. On the basis of National Forestry Database potential natural forest community database of forests were created for the present and future prediction also. According to our results, case of forest and forest steppe habitats high species and structural diversity (fragmented forest stands with grasslands and shrubs) can report higher adaptation. Usage of non native tree species only be possible if new circumstances are not suitable in any case for native habitats and taxa.
\end{abstract}

Keywords: climate change, tree species composition, potential range, assisted migration, potential natural forest community. 


\section{BEVEZETÉS}

A globális klímaváltozás jelenleg is érzékelhető erdőkre gyakorolt hatásai a jövőben várhatóan fokozódnak a Kárpát-medencében (Mátyás 2009, Barcza et al. 2011, Bartholy et al. 2011). A termőhelyek átalakulása a melegedés, szárazabbá válás és a tápelemellátottság növekedésének irányába (többlet szén-dioxid és nitrogén) mutat. A prognosztizált folyamatok nyilvánvalóan hatnak a fafajok elterjedésére, ökológiai viselkedésére, a növénytársulások faji, szerkezeti és müködési jellemzőire. A témával kapcsolatos magyarországi kutatások elsősorban az utóbbi évtizedek erdészetileg fontos, állományalkotó fafajokat érintő erdőpusztulásaira (lucfenyő, bükk, kocsányos tölgy, kocsánytalan tölgy) koncentráltak (Berki 2007, Kotroczó et al. 2007, Molnár \& Lakatos 2007, Somogyi 2007, Mátyás et al. 2010). A várható változások becslése során nem szabad elfeledkezni azonban a többi honos állományalkotó vagy elegy fafajról sem, melyek az erdőtársulásokban ökológiai szempontból fontos szerepet töltenek be és alkalmazkodási lehetőséget kínálhatnak az erdészet és a természetvédelem számára egyaránt.

A bizonyosan bekövetkező, de pontosan nehezen jósolható átrendeződési folyamatok becsléséhez fajokra és társulásokra fókuszáló módszereket egyaránt alkalmaztunk. A módszerek változatosságát a várható folyamatok komplexitása, valamint a becslési bizonytalanságok csökkentésének igénye indokolta.

Növényi tulajdonságokon alapuló értékelési módszer segítségével becsültük a Magyarországon őshonos fafajok érzékenységét és ezek értékeinek különbségeiből a tipizált öszszetételü erdőtársulás-csoportok várható átrendeződését.

A honos és inváziós fafajok Magyarországra vonatkozó potenciális és prognosztikus elterjedési mintázatát térinformatikai módszerekkel modelleztük kiválasztott példafajok segitségével (virágos kőris, csertölgy, nyugati ostorfa), alapozva a Magyarországi Flóratérképezési Program (Király 2003) eredményeként megjelent Magyarország edényes növényfajainak elterjedési atlaszára (Bartha et al. 2015).

Az elméleti jellegű értékeléseket nagyszámú terepi felvétel tapasztalataival egészítettük ki az egyes fafajok érzékenységének pontosabb becslése érdekében. Természetes erdőkben egy fafaj jövőbeli jelenléte vagy hiánya alapvetően azon múlik, hogy fel tud-e újulni. Másfelöl főleg az erdőgazdálkodás szempontjából lényeges, hogy Európa jelentős részén a klímaváltozással együtt járó, és várhatóan egyre gyakoribbá váló szélsőségesen száraz nyarak hatására mekkora az adott állomány mortalitása, azaz a törzsszám hány százaléka éri meg a vágásérettségi kort.

Elemzéseink kitértek arra is, hogy lehetséges-e a várhatóan visszaszoruló fafajok cseréje olyan nem öshonos fafajokra, melyek inváziós veszélyt nem jelentenek. Ezek a cserelehetőségek, az emberi segítséggel történő „fajvándorlás” (assisted migration, assisted colonisation) lehetőséget jelenthet a probléma megoldásában (Mclachlan et al. 2007, Hoegh-Guldberg et al. 2008, Richardson et al. 2009, Schwartz et al. 2012).

A társulás alapú megközelítés esetében a jelen és a jövő összehasonlítását a potenciális természetes erdőtársulás (PTE) koncepcióra támaszkodva végeztük (Bartha 2005, Bartha 
et al. 2014). Hasonló hazai kutatást jelent a MÉTA terepi felmérései alapján felépített, a potenciális természetközeli vegetációra vonatkozó térképes becslés, amely a szerzők tervei szerint a jövőben szintén összeköthetővé válik prognosztikus klímaadatokkal (Molnár et al. 2008, Somodi et al. 2017).

A jövőben várhatóan olyan termőhelytípus változatok alakulhatnak ki, melyekhez nem illeszkednek a jelenleg használatos erdőtársulás-csoportok rendszerébe tartozó kategóriák. A társulások fafajainak eltérő érzékenységéből adódó dinamika szintén olyan közösségeket tehet potenciálissá, melyekre jelenleg nincsenek definíciók. A jövőre vonatkozó térinformatikai adatbázis kategóriarendszere esetében azért választottuk mégis alapnak a jelenleg használt erdőtársulás csoportokat, mert a PTE előfordulási mintázat átrendeződésének célja nem a potenciális fajösszetétel változásának nagyon pontos modellezése (ez sok esetben az aktuális állapotokra vonatkozóan is rendkívül nehéz feladat), hanem olyan országos kép felvázolása, mely alapján a szakmai közönség - a jelenlegi erdőtársulások rendszerének ismeretében - a termőhelyek változásának irányáról és mértékéröl reális értékelést kap.

\section{ANYAG ÉS MÓDSZER}

\section{Erdőtársulások átrendeződési lehetőségei a fafajok eltérő érzékenysége alapján}

Elemzésünk során a Magyarországon bizonyítottan őshonos fafajok mellett fajlistánkra kerültek olyan fafajok is, melyek őshonossága nem tisztázott (pl. szelídgesztenye) vagy korábbi tudományos munkákban komolyabban felvetödött (pl. közönséges jegenyefenyő).

Összegyüjtöttük azokat a növényi tulajdonságokat, melyek összefüggésbe hozhatók a fafajok klímaváltozással kapcsolatos válaszreakcióival. Az értékelésbe bevont attribútumok négy csoportba sorolhatók: társuláspreferencia, horizontális és vertikális elterjedés, ökológiai igények, alkalmazkodóképesség. A társuláspreferencia során a fajokhoz tipikus erdőtársulásokat rendeltünk. A horizontális és vertikális elterjedés komponensei: areatípus, areaperemi helyzet, areadiszjunktság, magassági elterjedés. Vizsgált ökológiai igények: kontinentalitás, hőigény, vízigény. Az alkalmazkodóképesség értékelése az életmenet stratégia, a szukcessziós jelleg, a szociális magatartás típus, a degradációtürés, a vegetatív megmaradóképesség és a vegetatív terjedőképesség alapján történt.

Az értékelés során az egyes jellemzők kategóriái negatív és pozitív értékeket kaptak a várható klimatikus változásokkal kapcsolatos érzékenység szerint, melyeket súlyoztunk és összegeztünk a korábban említett négy értékelési szempontnak megfelelően. Attól függően, hogy a négy fő attribútum csoportból hány esetében kapott kiugró értékeket az adott fafaj, a következő kategóriákba soroltuk őket: „erősen érzékeny”, „mérsékelten érzékeny”, „mérsékelten pozitív” és „erősen pozitív reakció” a klímaváltozás hatásaira.

A fafajokhoz rendelt érzékenységi kategóriák önállóan csak általánosságban tekinthetők érvényesnek. A kapott adatbázis praktikus módon akkor válik alkalmazhatóvá, ha azt ösz- 
szedolgozzuk a Magyarországon jellemző erdőtársulások fafaj összetételét tartalmazó adatbázissal, melyet Bartha (2012) munkája alapján állítottunk össze. Ebben az esetben ténylegesen egy termőhelyen zajló elörevetített vegetációdinamikai folyamatokra tudunk következtetni az adatokból. A fafajok értékei, érzékenységi kategóriái közötti kontrasztból becsülhetővé válnak az elegyarány változások, dominancia viszonyok átalakulásai. A társulások változásainak becsléséhez az érzékenységi kategóriákon kívül figyelembe kell venni a társulásra jellemző termőhelyi adottságokat (klímarégió, vízháztartás, kitettség, egyéb edafikus tényezők), az egyes fajok életmenet tulajdonságait, szukcessziós jellegét, ökológiai türőképességét, élöhely spektrumát, a társulások hazai előfordulásainak érzékenységét, becsült regenerációs képességét, valamint az aktuálisan tapasztalható átalakulási folyamatokat.

\section{Erdőtársulások átrendeződési folyamatai terepi vizsgálatok alapján}

Faállomány egészségügyi- mortalitási, cönológiai, valamint a természetes felújulást megfigyelő vizsgálatokat végeztünk az elmúlt években az ország különböző klímájú tájain. Az eddig felmért 500 erdőrészlet közül 180-200 száraz erdő volt, amelyekben nemcsak a szárazságra érzékeny fafajok vizsgálatára koncentráltunk, hanem figyelemmel voltunk a szárazságtoleráns fafajok vitalitására, felújulására, a lombkorona szintbe növekedésükre is.

A kutatás részeként 50-60 évvel ezelötti cönológiai felvételek megismétlését végeztük el. Az újulat létének, vagy hiányának több évtizedes időtávú összevetése tekintetében lényeges, hogy az adott erdőrészleten belül ugyanolyan termőhelyi (domborzati) - tehát mikroklimatikus - adottságok között történt a megismételt felvételezés, mint 50-60 évvel ezelőtt. A kocsánytalan tölgy felújulása tekintetében lényeges volt annak figyelembe vétele, hogy az elődök felvételében volt-e fiatal kocsánytalan tölgy a felső cserjeszintben (B1) vagy az alsó lombkoronaszintben (A2), illetve volt-e kocsánytalan tölgy a felső lombkoronaszintben (A1). Olyan helyszínek is voltak, hogy az elödöknél a 20 × 20 méteres kvadrátban volt kocsánytalan tölgy újulat, de az A1-szintben nem volt. A mi felvételeinken, ahol nem volt kocsánytalan tölgy az A1-ben, ott sehol sem volt újulata. Rögzítettük azt is, hogy volt, vagy van-e tölgy(vagy más fafaj) pusztulás az egyes helyszíneken. Ha volt pusztulás, akkor jegyzőkönyveztük, hogy milyen fafajok újulnak fel a kialakult kisebb-nagyobb lékekben.

Természetes újulatnak tekintettük a B1-, illetve az A2-szintbe felnőt egyedeket. Az aljnövényzeti $(\mathrm{C})$ szintben levő magoncokat azért nem tekintettük (kutatásunk szempontjából) újulatnak, mert jóllehet számos állományban tapasztaltunk pl. viszonylag bőséges kocsánytalan tölgy magonc borítást, de a B1-, é A2- szintben nem, vagy elvétve láttunk néhány egyedet.

A cönológiai vizsgálatok mellett felújulási és mortalitási vizsgálatokat is végeztünk a dendometriai és állományegészségügyi vizsgálatokra kiválasztott kocsánytalan tölgyesben az országot átívelő klímagradiens mentén. 
Minden alkalmazott módszer esetében, a vizsgált területeken különös figyelemmel voltunk a lékek, erdőszélek és vadkizárt állományrészek felújulásának vizsgálatára. Egy természetes szerkezetű erdő (őserdő) sosem zárt lombkoronájú, mivel az idős és/vagy széldöntött fák helyén a lékek keletkeznek, amelyekben van annyi fény, hogy a fényigényesebb fafajok is fel tudnak újulni. Az egykorú gazdasági erdők lombkoronája - ezzel szemben - viszonylag zárt, és a fényigényes tölgyfajok még jó magtermő évek után is csak az öregerdő levágása utáni fénygazdag környezetben tudnak valamelyest felújulni. A természetes felújulás vizsgálatát a tölgyek esetében ezért a nagyobb lékekre, erdőszegélyekre koncentráltuk.

Tekintettel az évtizedek alatt többszörösére növekedett vadlétszámra, különösen a vaddisznóállományra, kerítéssel elzárt tölgyesek felújulását is vizsgáltuk, ráadásul fénygazdag lékekben létesített vadkizárt területeken is.

\section{Potenciális cserefajok értékelése}

A potenciális cserefajok leválogatása során értékeltük az összes olyan európai fafajt, mely Magyarországon nem tekinthető őshonosnak (Bartha 1999). A cserjefaj és fafaj szétválasztást szintén az idézett irodalom alapján tettük meg. A tanulmány korábbi fejezetében értékelt őshonos fafajok listája kissé átfed a potenciális cserefajok listájával, részben az őshonosság szempontjából kétséges fafajok, részben az előzőekben ismertetett Magyarországon őshonos, de egyes tájainkon tájidegen cserefajok alkalmazhatóságának vizsgálata miatt (pl. ezüst hárs, szelídgesztenye, keleti gyertyán). Az utóbbi kiegészítéshez olyan fajokat soroltunk, melyek areája a Kárpát-medencében éri el északi határát. Felvettünk a listára olyan taxonokat is, melyek Magyarországon őshonos fafajok balkáni elterjedésủ alfajai.

A kialakított európai taxon lista elemzése az őshonos fafajok korábbi fejezetben ismertetett módszeréhez hasonlóan történt. A taxonok korábban tárgyalt jellemzöit kiegészitettük olyan attribútumokkal, melyek inváziós kockázatuk minél pontosabb becslését célozzák. A kategorizálásnál alkalmazott skálák egyes jellemzők esetében részben vagy teljesen megegyeznek az őshonos fajok elemzése esetében használtakkal, bizonyos esetekben új kategória rendszer alkalmazására került sor.

A potenciális cserefafajok értékelt jellemzőik és csoportjaik a következők:

Alkalmazhatóság: Társuláspreferencia („Társuláspreferencia” érték), Ökológiai igények („Vízigény” érték + „Hőigény” érték + „Kontinentalitás” érték), Vertikális és horizontális elterjedés („Areatípus” érték + „Magassági elterjedés” érték), Ökomorfológiai tulajdonságok („Ökomorfológiai” érték).

Kockázatbecslés: Kockázati érték („Életmenet stratégia, szukcessziós jelleg” érték × 2 + „Degradációtürés” érték + „Vegetatív terjedőképesség” érték $\times 2+$ + „Vegetatív megmaradóképesség” érték + „Magterjesztési mód” érték + „Magbank típus” érték) 
A taxonlista szürését az alkalmazhatóságot, valamint a kockázati veszélyt jellemző számértékek alapján végeztük, így elkülöníthetővé váltak az alkalmas, illetve nem alkalmas, és a kockázatos, illetve kevésbé kockázatos fajok.

A kapott fajlistát szükséges a fagytürésre vonatkozó adatok segítségével leszürni, mivel a szubmediterrán elterjedésű fajok esetében a fagy az egyik legjelentősebb limitáló tényező. A fagytürési értékeket szakirodalmi adatok (Roloff \& Bärtels 2006) segítségével, illetve az elterjedési területeket a fagytürési térképekkel összehasonlítva határoztuk meg.

Kiválasztott fafajok esetében (keleti gyertyán, komlógyertyán, magyar tölgy, magyaltölgy) európai areájuk jelenlegi klimatikus adatai alapján térinformatikai módszerekkel modelleztük aktuális és jövőbeli potenciális elterjedésüket. Az elemzés jelenlegi klímája az 1960-90-es időszak átlagértékeiből származtatott adatokon nyugszik (URL1, Hamann 2013). A jövőbeni klíma az RCP 4.5, 2041-2070-re vonatkozó modelladataiból származik, amit a német Max Planck Institute készített (AOGCM name: MPI-ESM-LR). Mivel a fajok az országhatáron túliak, így szükséges volt egy európai léptékü konzisztens klímaadatbázisra. A fafajok elterjedési adatainak forrása Mauri (2017) adatbázisa, amely 21 európai ország közel 600.000 validált elterjedési adatát tartalmazza összesen 200 fafajra vonatkozóan. A modellezés „R” környezetben történt a maximum entrópia módszer felhasználásával.

\section{Fafajok potenciális elterjedési mintázatainak modellezése}

A magyarországi flóratérképezés alapegysége a közép-európai flóratérképezés (Niklfeld 1971) által használt hálórendszer, mely a földrajzi fokhálózatra támaszkodik. A felmérési egység az alapmezők negyedelésével jött létre, az alapmezőnegyedek (kvadrátok) mérete így $6,25 \mathrm{~km} \times 5,55 \mathrm{~km}$ (Király \& Horváth 2000). Ezek a kvadrátok képezték a felmérés alapegységét, ezért a többi vizsgálandó háttértényezőt ezekre az alapmező negyedekre kellett vonatkoztatnunk. A domborzat, talaj, klíma paraméterek és az aktuális elterjedés között kerestünk összefüggéseket. A domborzat esetében a kvadrátokhoz rendeltük a magasságkülönbségeket, és a magassági adatok középértékét. A talajtani tényezők hozzárendelése a Magyar Tudományos Akadémia Talajtani és Agrokémiai Kutató Intézete által összeállitott AGROTOPO adatbázis alapján történt. A talajtani tényezők közül a talaj kémhatása és mésztartalma befolyásoló tényező az egyes növényfajok elterjedésében, ezért kvadrát szinten határoztuk meg a különböző kémhatású és mésztartalmú talajok (erösen savanyú, gyengén savanyú, felszíntől karbonátos, szikes talajok) területarányát. A limitáló környezeti tényezők megállapításához további klímaadatokat vontunk be az elemzésbe: erdészeti aszályossági index (FAl) (Führer 2010), éves csapadékösszegek átlaga (Péves), nyári hónapok csapadékösszegének átlaga ( $P_{\text {nyári) }}$, éves hőmérsékletek átlaga (Téves), nyári hónapok hömérsékletének átlaga ( $\left.T_{\text {nyári }}\right)$.

Az abiotikus tényezőkön túl az elemzés során figyelembe vettük a biotikus tényezőket is. Az általunk kiválasztott legalkalmasabb módszernek az $R$ statisztikai programcsomagban található beals smoothing elemzés (De Cáceres \& Legendre 2008) bizonyult. Kiválasztottuk 
a flóratérképezési adatbázisban szereplő 32 leggyakoribb taxont, majd leválasztottuk azon kvadrátokat, melyekben a leggyakoribb taxonok $90 \%$-a előfordul, ezen módszer segítségével szürtük le a kontroll kvadrátokat. A leggyakoribb fajokat a felmérők ismerik, így a heterogén fajtudás ezzel a módszerrel többé-kevésbé kizárható. A leggyakoribb fajok potenciálisan a kvadrátokban nagy valószínüséggel fordulnak elő, tehát feltételezhetjük, hogy bizonyos mértékben függetlenek a környezeti háttérváltozóktól. Az elemzés a taxonok asszociáltságán alapul, tehát a kontroll kvadrátokban kiszámoltuk, hogy az egyes taxonok milyen valószínűséggel fordulnak elő egymáshoz viszonyítva. Ezekből a valószínűségekből lehetett vonatkoztatni a jósolt fajkészletre, illetve a taxonok jósolt előfordulására. Az elemzésnél azon kvadrátokban fogadtuk el a jósolt előfordulást, ahol legalább 90\%-os valószínűséggel fordulhat elő az adott taxon. Eredményként minden egyes taxonra kaptunk egy jósolt elöfordulást, a kvadrátokra egy jósolt teljes fajkészletet.

A kiválasztott fás szárú taxonokra ökológiai limitáló faktorokat állapítottunk meg, melyek meghatározó szerepet játszhatnak az elterjedésben. Egy döntési fa segítségével a limitáló tényezők között prioritási sorrendet állítottunk fel, majd így szürtük le azon kvadrátokat, melyek potenciálisan alkalmasak lehetnek az adott faj megjelenésére.

\section{Potenciális természetes erdőtársulások változásának becslése}

A potenciális természetes erdőtársulások aktuális elterjedési mintázatát tükröző térinformatikai adatbázist, mely a kiinduló állapotokat jellemzi és a viszonyítási alapot jelenti, Bartha et al. (2014) munkájára alapozva építettük fel. Az adatbázist az idézett tanulmányban leírt állapotához képest továbbfejlesztettük, erdészeti tájanként javítottuk a helyi sajátosságoknak megfelelően, valamint korrigáltuk azokat a hibákat (pl. nem létező termőhelytípus változatok), melyek a kiinduló üzemtervi adatokból származnak.

A klimatikus változások mértékének becsléséhez minden erdőrészlethez hozzárendeltük az 1981-2010 és a 2041-2070 közötti erdészeti aszályossági index (FAl) értékét, majd kiszámítottuk különbségüket.

Erdőtársulás-csoportokból álló változási sorokat állítottunk fel, a kiinduló PTE adatbázis rendszerét felhasználva, bizonyos társulások esetében azokat módosítva, átmeneti kategóriákkal kibővitve. Az erdőrészletek PTE kategóriáinak jövőre vonatkozó módosítása a FAI értékek különbségén $(\Delta \mathrm{FAl})$ alapszik:

- Bükkösök $\rightarrow \Delta \mathrm{FAl}=0,625 \rightarrow$ Bükkösök $\times$ Gyertyános-kocsánytalan tölgyesek $\rightarrow \Delta \mathrm{FAl}=$ $0,625 \rightarrow$ Gyertyános-kocsánytalan tölgyesek $\rightarrow \Delta \mathrm{FAl}=0,625 \rightarrow$ Gyertyános-kocsánytalan tölgyesek $x$ Cseres-kocsánytalan tölgyesek $\rightarrow \Delta \mathrm{FAl}=0,625 \rightarrow$ Cseres-kocsánytalan tölgyesek $\rightarrow \triangle \mathrm{FAl}=0,3125 \rightarrow$ Cseres-kocsánytalan tölgyesek $\mathrm{x}$ Mész- és melegkedvelö tölgyesek $\rightarrow \Delta \mathrm{FAl}=0,3125 \rightarrow$ Mész- és melegkedvelö tölgyesek $\rightarrow \Delta \mathrm{FAl}=0,3125$ $\rightarrow$ Mész- és melegkedvelö tölgyesek x Bokorerdő $\rightarrow \Delta \mathrm{FAl}=0,3125 \rightarrow$ Bokorerdő $\rightarrow$ $\Delta \mathrm{FAl}=1,25 \rightarrow$ nem erdő termőhely. 
- Mészkerülő bükkösök $\rightarrow \Delta \mathrm{FAl}=0,625 \rightarrow$ Mészkerülő bükkösök $x$ Mészkerülő gyertyános-tölgyesek $\rightarrow \Delta \mathrm{FAl}=0,625 \rightarrow$ Mészkerülö gyertyános-tölgyesek $\rightarrow \Delta \mathrm{FAl}=0,625 \rightarrow$ Mészkerülő gyertyános-tölgyesek $x$ Mészkerülő tölgyesek $\rightarrow \Delta F A l=0,625 \rightarrow$ Zárt mészkerülö tölgyesek $\rightarrow \Delta \mathrm{FAl}=1,25 \rightarrow$ Nyílt mészkerülő tölgyesek $\rightarrow \Delta \mathrm{FAl}=1,25 \rightarrow$ nem erdő termőhely.

- Zárt lösztölgyesek (FAl $1981-2010<=7.25) \rightarrow \Delta \mathrm{FAl}=1,25 \rightarrow$ Nyílt lösztölgyesek $\rightarrow \Delta \mathrm{FAl}=$ $1,25 \rightarrow$ nem erdő termöhely.

- Nyílt lösztölgyesek (FAl $\left.{ }_{1981-2010}>7.25\right) \rightarrow \Delta \mathrm{FAl}=1,25 \rightarrow$ nem erdő termőhely.

- Zárt homoki tölgyesek ( $\left.F A l_{1981-2010}<=7.25\right) \rightarrow \Delta F A l=1,25 \rightarrow$ Nyilt homoki tölgyesek $\rightarrow$ $\triangle \mathrm{FAl}=1,25 \rightarrow$ nem erdö termöhely.

- Nyílt homoki tölgyesek (FAl1981-2010 $\rightarrow 7.25) \rightarrow \Delta F A l=1,25 \rightarrow$ nem erdő termőhely.

- Borókás-nyárasok $\rightarrow \Delta \mathrm{FAl}=1,25 \rightarrow$ nem erdő termőhely.

- Sziki tölgyesek $\rightarrow \Delta \mathrm{FAl}=1,25 \rightarrow$ nem erdö termőhely.

- Gyertyános-kocsányos tölgyesek $\rightarrow \Delta \mathrm{FAl}=1,25 \rightarrow$ Zárt kocsányos tölgyesek.

- Cseres-kocsányos tölgyesek $\rightarrow \Delta \mathrm{FAl}=1,25 \rightarrow$ Nyílt cseres-kocsányos tölgyesek.

\section{EREDMÉNYEK ÉS MEGVITATÁSUK}

\section{Erdőtársulások átrendeződési lehetőségei a fafajok eltérő érzékenysége alapján}

A várhatóan visszaszoruló vagy előnyhöz jutó fafajok értékelése erdőtársulás csoportonként lehetséges, olyan módon, hogy vagy az értékelési szempontok alapján kapott pontokat vetjük össze vagy a 4 szempontot együttesen jellemző kategóriák kontrasztját elemezzük (1. táblázat).

$A$ várható átrendeződési folyamatok két módon értelmezhetők. Az egyik lehetőség az erdőtársulások tipikus komponens fafajaiból kiindulni és azok egymáshoz viszonyított érzékenységét mérlegelni. Másik alkalmazkodási út lehet, olyan fajok elöretörése vagy elönyben részesítése, melyek aktuálisan nem illeszkednek az őshonos fafajú társulásokba, de környezetükben elérhető távolságban vannak olyan erdőtársulások, melyek fafajai alkalmasabbnak értékelhetők a változó klímában. Az első lehetőség enyhébb, a második drasztikusabb éghajlati változások esetén kaphat nagyobb hangsúlyt.

Az átrendeződési lehetőségeket a legfontosabb többletvízhatáshoz nem kötődő erdőtársulás-csoportokat áttekintve, néhány jellemző példa segítségével szemléltetjük. $A$ becsült változások jövőbeli megvalósulásának minden esetben feltétele az erdőállományok természeteshez közelítő elegyessége. Országos és regionális kutatások, valamint az Országos Erdőállomány Adattár adatai szerint, az őshonos fafajú erdőállományaink elegyességi mutatói jelentősen elmaradnak ettől, az alkalmazkodást lehetővé tevő szinttől (Bartha et al. 2003, Standovár et al. 2017). 
1. táblázat: Többletvízhatástól független erdőtársulás-csoportok jellemző fafajai összetételi jelentőségük és a fafajokra jellemző általános érzékenységi kategóriák feltüntetésével (D: állományalkotó faj, E: fontosabb elegyfaj, SZ: szálanként előforduló ritkább faj, R: egyes régiókban tipikus faj, Ö: egyes ökológiai változatokban jellemző faj, A: adventív faj, piros - erősen érzékeny, rózsaszín - mérsékelten érzékeny, világoszöld - mérsékelten pozitív reakció, sötétzöld - erösen pozitív reakció).

Table 1: Typical tree species composition of forest community groups on sites without surplus water, compositional importance and sensitivity of tree species are marked (D: stand-forming, E: major admixed tree species, SZ: single mixing, R: typical for some regional variant, Ö: typical for some ecological variant,

A: adventive, red - high sensitive, pink - moderate sensitive, light green - moderate positive reaction, dark green - high positive reaction).

\begin{tabular}{|c|c|c|c|c|c|c|c|c|c|c|c|c|c|c|c|c|c|c|c|c|c|}
\hline & 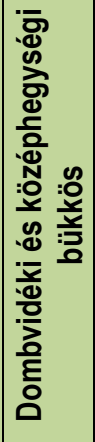 & 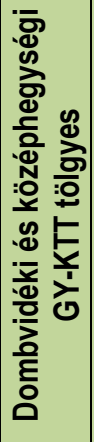 & 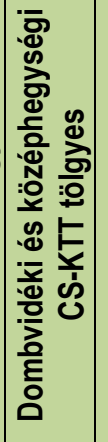 & 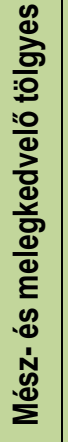 & $\begin{array}{l}\text { 흐 } \\
\text { 응 } \\
\text { 흥 } \\
\text { 호 }\end{array}$ & 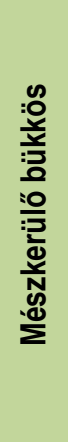 & 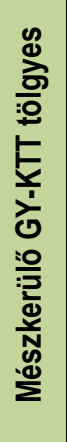 & 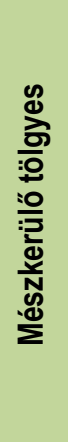 & 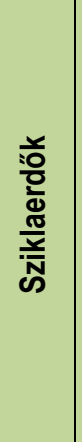 & 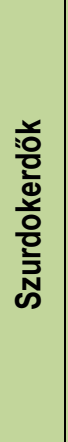 & 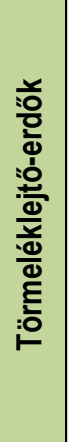 & 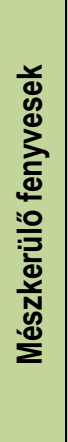 & 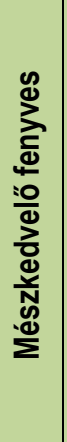 & 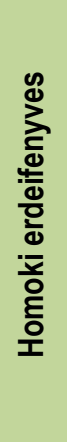 & 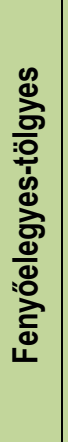 & 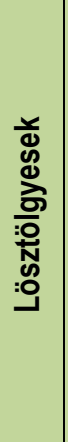 & 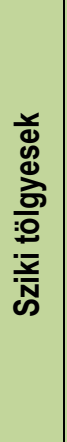 & 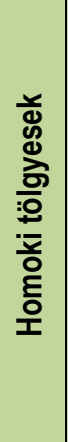 & 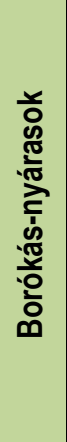 & 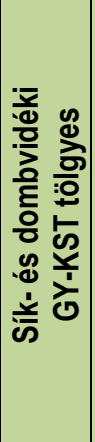 & 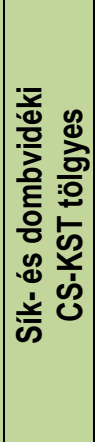 \\
\hline Acer campestre & & $E$ & $\mathrm{E}$ & $\mathrm{E}$ & E & & & & $E$ & $E$ & $E$ & & & & & $E$ & $E$ & $E$ & & $E$ & $E$ \\
\hline Acer platanoides & SZ & $E$ & & & & & & & $E$ & $E$ & $E$ & & & & & & & & & $S Z$ & \\
\hline Acer pseudoplatanus & E & & & & & & & & $E, S Z$ & E & E & & & & & & & & & & \\
\hline Acer tataricum & & & $E$ & $\mathrm{R}$ & $E$ & & & & & & & & & & & $E$ & $E$ & $E$ & & $E$ & \\
\hline Alnus glutinosa & & & & & & & & & & & & & & & & & & & & & SZ \\
\hline Betula pendula & SZ & & & & & $E$ & $E$ & $E$ & & & & $E$ & & & $E$ & & & SZ & & & $E$ \\
\hline Carpinus betulus & $E$ & $D$ & & & & & $D$ & $S Z$ & $S Z$ & $S Z$ & $S Z$ & & & & $\mathrm{D}$ & & & & & $D$ & \\
\hline Carpinus orientalis & & & & & RÖ & & & & & & & & & & & & & & & & \\
\hline
\end{tabular}




\begin{tabular}{|c|c|c|c|c|c|c|c|c|c|c|c|c|c|c|c|c|c|c|c|c|c|}
\hline & 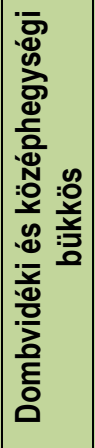 & 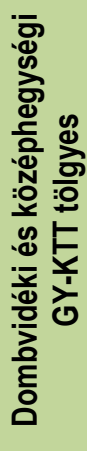 & 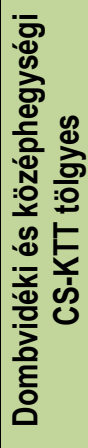 & 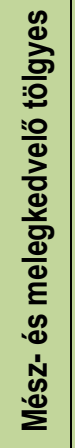 & 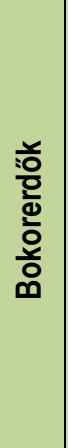 & 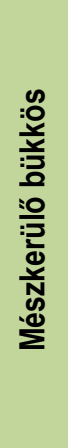 & 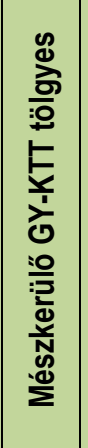 & 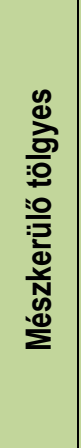 & 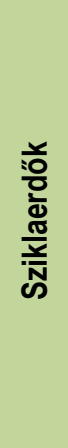 & 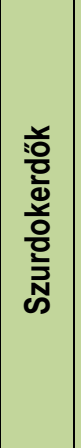 & 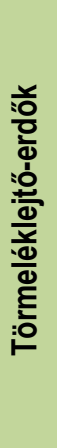 & 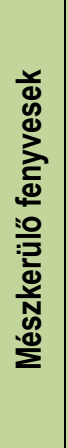 & 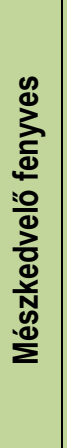 & 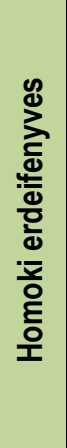 & 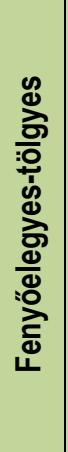 & 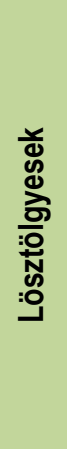 & 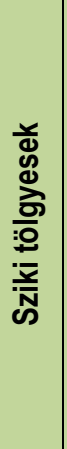 & 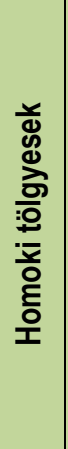 & 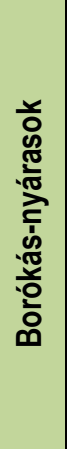 & 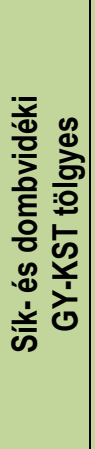 & 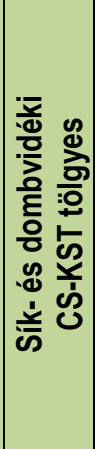 \\
\hline Castanea sativa & & $\mathrm{R}$ & & & & $\mathrm{R}$ & $\mathrm{R}$ & R SZ & & & & & & & & & & & & & \\
\hline Cerasus avium & SZ & $E$ & & & & & & & & $E$ & $E$ & & & & & & & & & $E$ & \\
\hline Cerasus mahaleb & & & & & $E$ & & & & & & & & & & & & & & & & \\
\hline Fagus sylvatica & D & $E$ & & & & D & SZ & SZ & $E, D$ & SZ & SZ & & & & D & & & & & & \\
\hline $\begin{array}{l}\text { Fraxinus angustifolia } \\
\text { ssp. danubialis }\end{array}$ & & & & & & & & & & & & & & & & & $E$ & & & $\mathrm{R}$ & \\
\hline Fraxinus excelsior & $E$ & $E$ & & & Ö & & & & $E$ & $E$ & $E$ & & & & & & & & & & \\
\hline Fraxinus ornus & & & SZ & $\mathrm{R}$ & D & & & & E & $\mathrm{R}, \mathrm{O}$ & $\mathrm{R}$ & & & E & & & & & & & \\
\hline Malus sylvestris & & & & & & & & & & & & & & & & SZ & & & & $E$ & \\
\hline Pinus sylvestris & & & & & & $\mathrm{R}$ & R SZ & $\mathrm{R}$ & D & & & $\mathrm{D}$ & $D$ & $\mathrm{D}$ & $\mathrm{D}$ & & & & & & SZ \\
\hline Populus alba & & & & & & & & & & & & & & & & & & $E$ & $D$ & & \\
\hline Populus tremula & $S Z$ & & & & & $E$ & $E$ & SZ & & & & $E$ & & & $E$ & & & SZ & & & \\
\hline Pyrus pyraster & & & $E$ & $E$ & & & & & & & & & & & & $E$ & $E$ & $E$ & $S Z$ & & $E$ \\
\hline Quercus cerris & & $E$ & $D$ & R-D & $\mathrm{E}$ & & & SZ & & & & & & $E$ & & $E$ & & & & & D \\
\hline Quercus petraea & SZ & D & D & D & $S Z$ & $E$ & D & D & $E$ & & & & & & $D$ & $E$ & & & & SZ & $S Z$ \\
\hline
\end{tabular}




\begin{tabular}{|c|c|c|c|c|c|c|c|c|c|c|c|c|c|c|c|c|c|c|c|c|c|}
\hline & 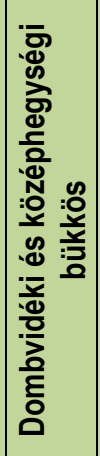 & 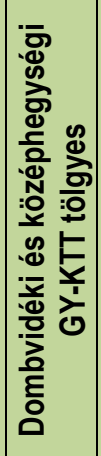 & 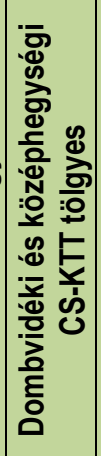 & 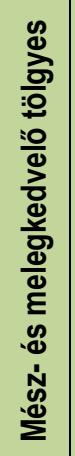 & 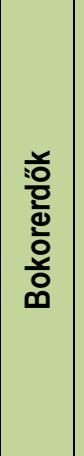 & 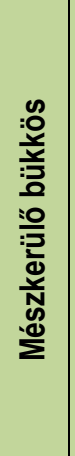 & 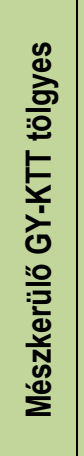 & 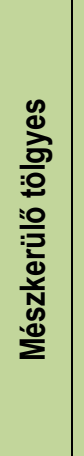 & 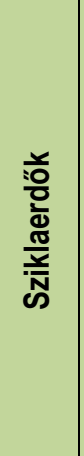 & 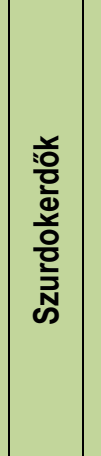 & 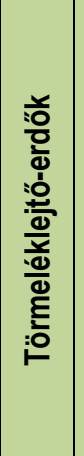 & 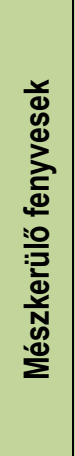 & 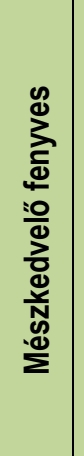 & 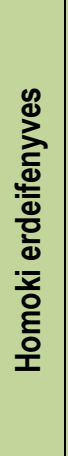 & 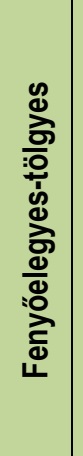 & 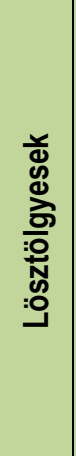 & 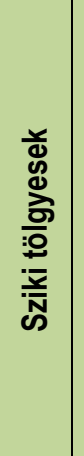 & 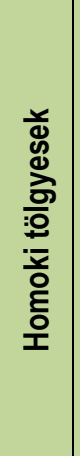 & 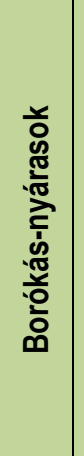 & 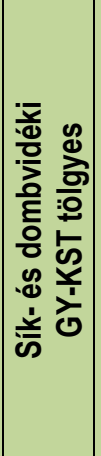 & 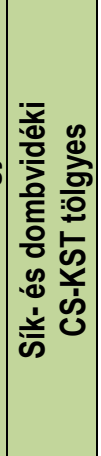 \\
\hline Quercus pubescens & & & SZ & $\mathrm{D}$ & $\mathrm{D}$ & & & & $\mathrm{SZ}$ & & & & & & & & & & & & SZ \\
\hline Quercus robur & & & & & & & & & & & & & & $E$ & $\mathrm{D}$ & $\mathrm{D}$ & $\mathrm{D}$ & $\bar{D}$ & SZ & $D$ & $D$ \\
\hline Quercus virgiliana & & & $S Z$ & $\mathrm{D}$ & & & & & & & & & & & & $\mathrm{Sz}$ & & $\mathrm{SZ}$ & & & \\
\hline Salix caprea & $S Z$ & & & & & & & & & & & & & & & & & & & & \\
\hline Sorbus aria & & & & & & & & & $\mathrm{E}$ & & $E$ & & $S Z$ & & & & & & & & \\
\hline Sorbus aucuparia & & & & & & $E$ & $E$ & $S Z$ & $E$ & & & $\mathrm{E}$ & & & & & & & & & \\
\hline Sorbus domestica & & & $E$ & $E$ & $E$ & & & & & & & & & & & & & & & & \\
\hline Sorbus torminalis & & & $E$ & $E$ & $E$ & & & & $E$ & & & & & & & & & & & & \\
\hline Tilia cordata & $S Z$ & $E$ & $S Z$ & & & & $E$ & & $E$ & $E$ & $E$ & & & & & & & & & $E$ & \\
\hline Tilia plathyphyllos & $E$ & $S Z$ & & & & & & & $E$ & $E$ & $E$ & & & & & & & & & & \\
\hline Tilia tomentosa & $R$ & $\mathrm{R}$ & $R$ & $\mathrm{R}$ & & & & & & R, Ö & $\mathrm{R}$ & & & & & & & & & $R$ & \\
\hline Ulmus glabra & $E$ & & & & & & & & SZ & $\mathrm{E}$ & & & & & & & & & & & \\
\hline Ulmus minor & & & $E$ & $E$ & $S Z$ & & & & & & & & & & & $E$ & $E$ & $E$ & & $E$ & $E$ \\
\hline
\end{tabular}


Az elemzés alapján a klímaregionális üde erdőtársulás-csoportok (bükkösök, gyertyános-kocsánytalan tölgyesek) esetében potenciálisan előnyhöz jutó fafajok közé tartozik a korai juhar (Acer platanoides), a madárcseresznye (Cerasus avium) és a kontinentalitást jobban elviselö kislevelü hárs (Tilia cordata). A regionális jelentőségü, balkáni areával rendelkező ezüst hárs (Tilia tomentosa) tág élőhelypreferenciája szintén jó alkalmazkodási képességre utal. A közönséges bükk (Fagus sylvatica) várható visszaszorulásával, bükkösökben a nagylevelü hárs (Tilia platyphyllos) és a hegyi juhar (Acer pseudoplatanus) is elötérbe kerülhet.

A cseres-kocsánytalan tölgyesek, valamint a mész- és melegkedvelö tölgyesek esetében a kocsánytalan tölgy (Quercus petraea), mint fontos komponens fafaj visszaszorulása prognosztizálható. A jellemző elegyfafajok közül pozitív reakció várható a tatár juhar (Acer tataricum), virágos kőris (Fraxinus ornus), vadkörte (Pyrus pyraster), molyhos tölgy (Quercus pubescens), házi berkenye (Sorbus domestica) és barkócaberkenye (Sorbus torminalis) esetében. A mész- és melegkedvelő tölgyesek nagyobb fafajdiverzitása, valamint az érzékeny kocsánytalan tölgy alacsonyabb elegyaránya nagyobb lehetőséget enged a meglévő fajkészleten alapuló spontán vagy támogatott kompozícionális átrendeződésre.

Az erdők számára határtermőhelyen fekvő, természetes módon felnyíló bokorerdők és erdőssztyep erdők (lösztölgyesek, sziki tölgyesek, homoki tölgyesek, borókás-nyárasok) esetében különösen fontos a honos fafajokra támaszkodó alkalmazkodás, hiszen ennek alternatívája csak gyepek arányának növekedése lehet. Természetvédelmi szempontból nem feltétlen előnytelen forgatókönyv a nagyobb vertikális szerkezeti elemek arányainak eltolódása az erdö-gyep élőhelykomplexen belül, de elönyös, ha a fafajok egyedei, csoportjai meghatározó elemei maradnak a vegetációnak, alkalmazkodva a termőhely mozaikos szerkezetéhez. A növényi fajdiverzitás szempontjából az erdőfoltok, facsoportok és a gyepek között kialakuló szegélytársulások kiemelkedő jelentőségüek.

A szikladomborzatú erdők változatos fafajkészlete általánosságban jó esélyt ad a spontán alkalmazkodásra. Ennek gyakorlati megvalósulását akadályozhatja, hogy ezek az élőhelyfoltok sokszor kis kiterjedésủek és a tipizált fafajkészlet csak egy kisebb része van jelen az állományokban. Különösen a sziklaerdőkre és a törmeléklejtö-erdőkre érvényes, hogy a változatos kitettség változatos fafajösszetételt is jelenthet, ami a klíma átalakulása esetén fokozottabb sérülékenységgel jár. A szurdokerdők létrejöttét lehetővé tevő, a mikroklímát jelentősen befolyásoló edafikus tényezők a jövőben is érvényesülni fognak, de a módosuló makro- és mezoklímához képest viszonyítva. A szikladomborzatú erdők példája jól mutatja, hogy az erdőtársulások természetes alkalmazkodási képességének becsléséhez az állományok tényleges összetételét és a tájökológiai szempontokat egyaránt figyelembe kell venni.

Az előbbiekben tárgyalt összes erdőtársulás-csoport esetében kiemelendő a mezei juhar (Acer campestre), mely elegyfajként a gyertyános-tölgyesektől a bokorerdőkig és erdőssztyep erdőkig megtalálható. A széles élőhelyspektrum és a magas alkalmazkodóképesség arra utal, hogy változatos termöhelyi feltételek között juthat nagyobb szerephez a klímaváltozás következtében. 
A fajszegény mészkerülő erdők erdőtársulás-csoporton belüli rugalmassága mérsékelt, kevésbé érzékeny elegyfajainak egy része pionír karakterü (közönséges nyír, rezgő nyár). Számottevő elegyarány eltolódás esetén már mészkerülő bükkös helyett mészkerülő gyertyános-kocsánytalan tölgyesként vagy mészkerülő tölgyesként határozhatjuk meg az erdőállományt. A mészkerülő erdők állományainak jelentős részének esetében azzal is számolni kell, hogy a klíma változásával párhuzamosan, tájtörténeti okokból folytatódik a mészkerülő jelleg csökkenésének folyamata. Ennek következménye, hogy a klímaregionális erdőtársulások gazdagabb fajkészletének egyes fafajai már alkalmazhatóak lennének a termőhelyen, de nem biztos, hogy elérhető távolságban vannak a gyors, spontán betelepedéshez.

\section{Erdőtársulások átrendeződési folyamatai terepi vizsgálatok alapján}

Humid klímán az erdő „belső szukcessziójának” eredményeképpen még a bükk fel tud nőni a lombkoronaszintbe. A szárazabb tájak felé haladva a gyertyán egészen a 32-33-as Ellenberg indexű termőhelyekig jelen van, viszont e mezofil klímakategóriában jellemző rá a csúcsszáradás.

A madárcseresznye viszont jó egészségügyi állapotban megtalálható még a 35-ös Ellenberg-index értékig, igaz tömegessége messze elmarad a gyertyán mögött. Az akác csak a mezofil erdőkben, és csak kevés egyeddel jelenik meg a lombkorona szintben. A kocsánytalan tölgy felújulása még saját - viszonylag humid - állományaiban sem történik meg, leginkább a fényhiány miatt ugyanakkor néhány fényben gazdagabb és savanyú talajú, szárazságra hajló termőhelyen kinő a cserjeszintből. Továbbá a kocsánytalan tölgy felújulásának megítélése nem nélkülözheti a kerített vadkizárásos területek fás szukcessziójának figyelembe vételét. A kislevelü hárs virulensen nő föl a felső lombkoronaszintbe (A2) számos mezofil termőhelyen. A legszárazabb erdőkben kis elegyaránnyal jelenik meg a mezei szil, és meglepő, hogy néhány helyen a korai juhar is. A mezofil és a száraz erdők többségében a mezei juhar törekszik fává nőni a kisebb-nagyobb lékekben, a legszárazabb termőhelyeken pedig társul hozzá a virágos kőris és a sekély talajú erdőkben a mezei juharnál is nagyobb elegyaránnyal nő fává a kiszáradó tölgy egyedek helyén.

Adataink előzetes kiértékelése alapján is egyértelmüen látszik, hogy a jelenlegi még viszonylag humid és mezofil tölgyesekben és erdei fenyvesekben a gyertyán felújulása jelentős. A száraz tölgyesek, fekete fenyvesek termőhelyein a mezei juhar és a virágos kőris képes spontán állományokat alkotni.

A humid tájakon egy-két „főfafaj” is elegyfafajként is feltűnik, így pl. kocsánytalan tölgyesben a gyertyánon kívül a bükk, erdei fenyvesben pedig a kocsánytalan tölgy és a bükk is jól tolerálja a klímaváltozást, így e fafajok a lombkorona szintbe nőttek. 


\section{Potenciális cserefajok értékelése}

Fafajok értékelése növényi tulajdonságok adatbázisai alapján

Az előzőekben ismertetett módszerünkkel a következő fafajokat határoltuk le:

— Görög jegenyefenyö (Abies cephalonica)

- Szelídgesztenye (Castanea sativa)

— Török mogyoró (Corylus colurna)

- Balkáni kőris (Fraxinus pallisiae)

- Magas kőris alfaj (Fraxinus excelsior subsp. coriarifolia)

- Alacsony vadalma (Malus dasyphylla)

- Keleti platán (Platanus orientalis)

- Vastaggallyú körte (Pyrus nivalis)

- Magyar tölgy (Quercus frainetto)

- Hartwiss-tölgy (Quercus hartwissiana)

- Kocsányos tölgy alfaj (Quercus robur subsp. broteroana)

- Dárdáskaréjú kocsánytalan tölgy (Quercus dalechampii)

- Szürke (hamvas) tölgy (Quercus pedunculiflora)

— Erdélyi kocsánytalan tölgy (Quercus polycarpa)

- Szicíliai tölgy (Quercus sicula)

- Déli berkenye (Sorbus graeca)

- Begónialevelü hárs (Tilia dasystyla)

— Nagylevelü hárs alfaj (Tilia platyphyllos subsp. pseudorubra)

— Krími szil (Ulmus elliptica)

Az alábbi fajok nem feleltek meg a leválogatási kritériumoknak, áttekintésük és alaposabb vizsgálatuk mégis indokolt. Azonos nemzetségbe tartoznak vagy közeli rokonságban állnak olyan fontos magyarországi fafajokkal, melyek visszaszorulása, társulásaik átrendeződése a jövőben valószínüsíthető.

— Komlógyertyán (Ostrya carpinifolia)

- Keleti gyertyán (Carpinus orientalis)

- Balkáni bükk (Fagus moesiaca)

- Keleti bükk (Fagus orientalis)

- Tompakaréjú juhar (Acer obtusatum)

- Keskenylevelü kőris alfaj (Fraxinus angustifolia subsp. angustifolia)

- Keskenylevelü kőris alfaj (Fraxinus angustifolia subsp. oxycarpa)

- Francia juhar (Acer monspessulanum)

- Illír juhar (Acer hyrcanum)

- Hegyi juhar alfaj (Acer pseudoplatanus subsp. subobtusatum) 
A két fajlistában felsorolt fajok tovább szürhetők és potenciális hasznositthatóság szerint csoportosithatók.

A közönséges jegenyefenyő (Abies alba) hazánkban számottevő gazdasági jelentőséggel nem rendelkezik, ezért a fajt potenciálisan helyettesítö görög jegenyefenyő (Abies cephalonica) tényleges alkalmazása indokolatlan.

Bár leválogatási szempontjainknak megfelelt a Hartwiss-tölgy (Quercus hartwissiana) és a sziciliai tölgy (Quercus sicula), erős mediterrán karakterük és növényföldrajzi helyzetük okán legfeljebb csak hosszú távon jöhetnek szóba cserefajként.

Bizonyos fafajok Magyarországon kis populációkkal aktuálisan is előfordulnak vagy természetvédelmi, kultúrtörténeti szempontból fontosak. E fajok elegyként történő ültetése a fajok védelme szempontjából kívánatos, de erdészeti szempontból kisebb jelentőséggel rendelkeznek. Ebbe a csoportba sorolható a szelídgesztenye (Castanea sativa), az alacsony vadalma (Malus dasyphylla), a vastaggallyú körte (Pyrus nivalis) és a déli berkenye (Sorbus graeca).

Az Acer, Fraxinus és Ulmus nemzetség nem őshonos fafajokhoz sorolható taxonjainak (Acer obtusatum, Acer monspessulanum, Acer hyrcanum, Fraxinus pallisiae, Ulmus elliptica) mesterséges migrációval történő terjesztése, hatékony anemochor magterjesztésük és nemzetségük más, idegenhonos fajai esetében tapasztalható magas inváziós képessége miatt fokozott óvatosságot és további vizsgálatokat igényel.

A komlógyertyán (Ostrya carpinifolia), a keleti gyertyán (Carpinus orientalis) és az előző csoportban is említett francia juhar (Acer monspessulanum) mesterséges migrációba való részvételét faanyaguk alacsony hasznosithatóságán kívül az is akadályozza, hogy a helyettesítendő fafajok (pl. közönséges gyertyán) jellemző élőhelyei a potenciális cserefajokétól nagyban eltérő összetételűek. Ezek az élöhelyek legtöbbször több klímarégióval eltolva vagy jóval üdébb körülmények között helyezkednek el, így az eredetihez hasonló erdőtársulások stabilizálása ezekkel a fafajokkal nem lehetséges.

Feltételesen, további vizsgálatokat követöen javasolható taxonok a török mogyoró (Corylus colurna), keleti platán (Platanus orientalis), begónialevelű hárs (Tilia dasystyla). A török mogyoró inváziós potenciálja a tölgyekétől magasabb, de még mindig viszonylag alacsonynak mondható. Óvatosságra ad okot, hogy megfigyelések szerint egyes gyüjteményes kertekben erőteljesen, már szinte gyomosító jelleggel újul, így ennek a kérdéskörnek a megnyugtató tisztázása még további vizsgálatokat igényel. A közönséges mogyoróval (Corylus avellana) hibridizálódik, így genetikai állományára veszélyt jelenthet.

A legnagyobb biztonsággal javasolható taxonokat két csoportra oszthatjuk. Egyik csoportba azok az alfaj szintü, dél-európai elterjedésü taxonok tartoznak, melyek rendszertanilag közel állnak a helyettesitendő hazai alfajokhoz, inváziós kockázatuk mérsékelt, felhasználási lehetőségeik a hazai taxonokhoz hasonlóak. A hazai alfajoktól való genetikai különbözőségük elsősorban rövidtávon (erdészeti léptékban) jelenthet alkalmazkodási lehetőséget az erdőgazdálkodás számára. A csoportba a következő taxonok tartoznak: Fraxinus ex- 
celsior subsp. coriarifolia, Quercus robur subsp. broteroana, Tilia platyphyllos subsp. pseudorubra, Fraxinus angustifolia subsp. angustifolia, Fraxinus angustifolia subsp. oxycarpa, Acer pseudoplatanus subsp. subobtusatum.

A mesterséges migráció keretében eltérő fajokkal történő fafajcsere az alábbi fajok esetében javasolható: magyar tölgy (Quercus frainetto), erdélyi kocsánytalan tölgy (Quercus polycarpa), szürke (hamvas) tölgy (Quercus pedunculiflora), keleti bükk (Fagus orientalis), balkáni bükk (Fagus moesiaca). Életmenet stratégiájukból, szukcessziós jellegükböl (K-stratégista) adódóan és a tölgyekre, bükkökre jellemző terjedési módszerük miatt számottevő inváziós potenciállal nem rendelkeznek.

A szürke tölgy alkalmas lehet a kocsányos tölgy (Quercus robur) pótlására azokon az alföldi termőhelyeken, melyeken a klimatikus változások és / vagy a talajvíz szintjének drasztikus süllyedése nem teszi lehetővé az erdők őshonos tölgyfajokkal történő felújitását.

A magyar tölgy, az erdélyi és a dárdáskaréjú kocsánytalan tölgy taxonok a közönséges kocsánytalan tölgy helyettesítésére alkalmasak, elsősorban cseres-kocsánytalan tölgyesekben, valamint mész- és melegkedvelő tölgyesekben. A szekcióba tartozó fajok változatos módon hibridizálódnak, ami lehetőséget ad az optimális populációk kiválasztására ebből a tág genetikai spektrumból.

A közönséges bükk (Fagus sylvatica) és keleti bükk (Fagus orientalis) közötti széles átmenet a tölük nehezen elhatárolható balkáni bükkön (Fagus moesiaca) keresztül szintén adott.

\section{Fafajok értékelése európai léptékü térinformatikai modellezés alapján}

Kapcsolódva az előző értékelési módszeréhez, megvizsgáltuk 4 fafaj potenciális és prognosztikus elterjedését a jelenlegi area klimatikus tulajdonságai alapján. Csak olyan fafajok bizonyultak vizsgálhatónak, melyekről megbízható elterjedési adatokkal rendelkezünk és elterjedési területük nem túlságosan szük. A magyar tölgyet a számszerüsíthető adatokon nyugvó leválogatás során kaptuk eredményül. A keleti gyertyán és a komlógyertyán részletesebb vizsgálatát más honos fafajainkkal való közeli rokonságuk indokolja. A magyaltölgy (Quercus ilex) nem ment át a növényi tulajdonságokon alapuló szüröinken, a fafaj bevonása kontroll jelleggel, az előző módszer ellenőrzésének céljából történt.

Az alkalmazott modell eredményei szerint, a jelenlegi klimatikus körülményeket figyelembe véve, a magyar tölgy potenciális areája magában foglalja Dunántúl déli és középső részét. A klíma változásával a 2041-2070-es időszakra a fafaj számára alkalmas területek elsősorban a középhegységek (pl. Mátra, Bükk) keskeny hegylábi sávjaira és egyes dombvidékeinkre (pl. Kelet-Cserhát, Heves-Borsodi-dombság) tolódnak (1. ábra). 

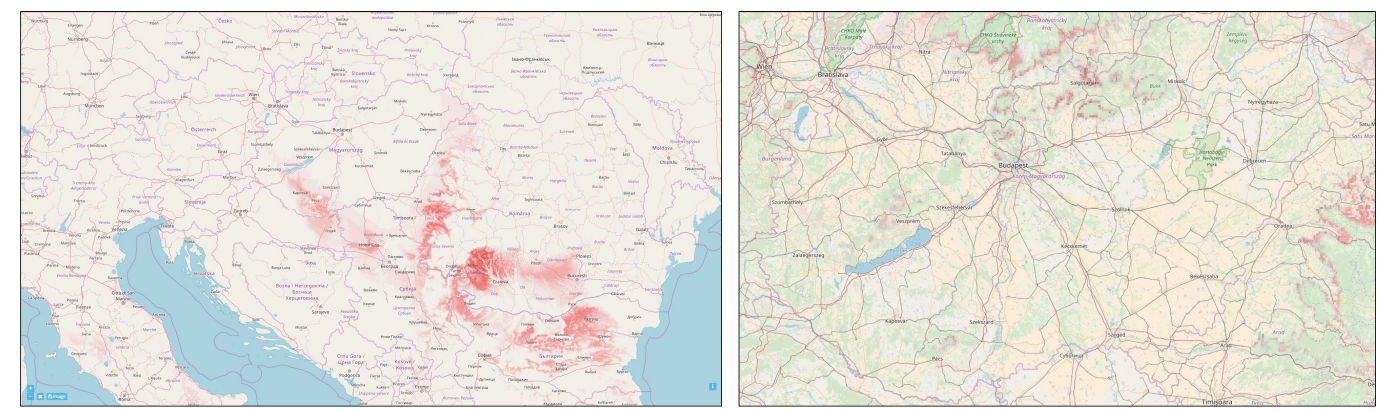

1. ábra: A magyar tölgy (Quercus frainetto) potenciális (bal) és prognosztikus (2041-2070) (jobb) elterjedése (0 - 0\% valószínüség, 1 - 100\% valószínüség) a „Maximum Entropy” módszer szerint végzett modellezés és RCP 4,5 forgatókönyv alapján.

Figure 1: Potential area of Quercus frainetto for present (left) and future (2041-2070) (right) (0 - 0\% feasibility, 1 - 100\% feasibility) using „Maximum Entropy” method and RCP 4,5 scenario.

A keleti gyertyán klíma alapján becsült potenciális areája kiterjed a Dunántúl déli és délnyugati részére. A 2050-re vonatkozó térkép szerint a fafaj prognosztikus elterjedésének magyarországi súlypontja a Dunántúl nyugati részére helyeződik, valamint szigetszerüen a középhegységek magasabb régióiban is alkalmas lesz a klíma számára. Figyelembe véve a Nyugat-magyarországi peremvidék klímán kívüli termőhelyi tényezőit, a fafaj potenciális előfordulása a területen kétséges (2. ábra).
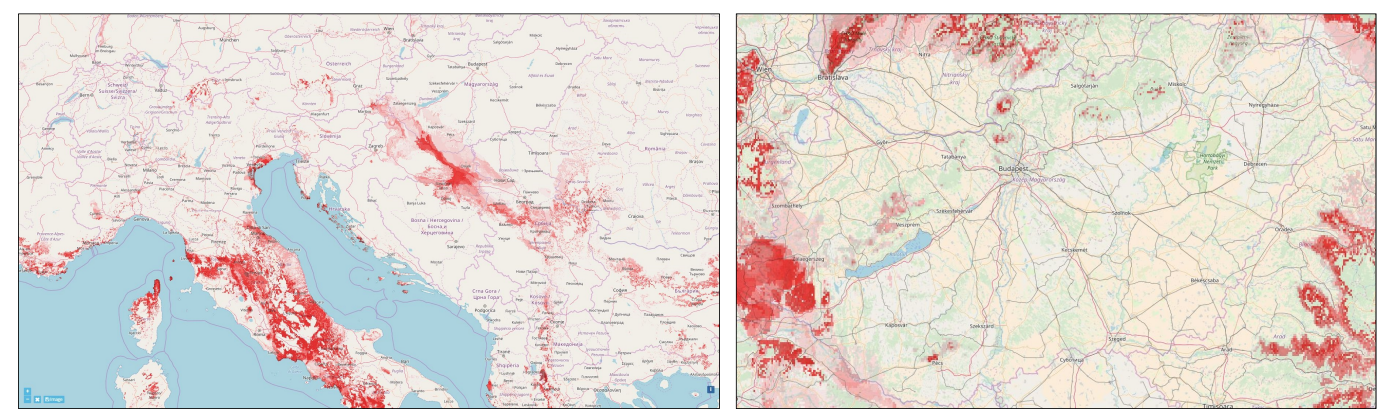

2. ábra: A keleti gyertyán (Carpinus orientalis) potenciális (bal) és prognosztikus (2041-2070) (jobb) elterjedése (0 - 0\% valószínűség, 1 - 100\% valószínűség) a „Maximum Entropy” módszer szerint végzett modellezés és RCP 4,5 forgatókönyv alapján.

Figure 2: Potential area of Carpinus orientalis for present (left) and future (2041-2070) (right) (0 - 0\% feasibility, 1 - 100\% feasibility) using „Maximum Entropy” method and RCP 4,5 scenario.

A komlógyertyán számára az aktuális klíma nem megfelelő az ország területén. A jövőben csupán a Vendvidék lehet alkalmas a fafajnak, a modell itt is csak alacsony valószínüséget jelez (3. ábra). 

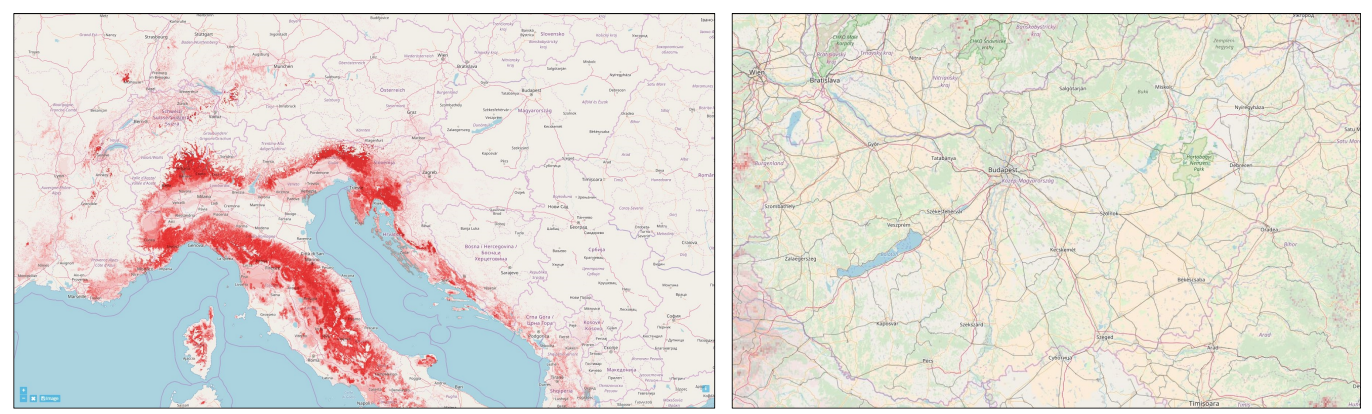

3. ábra: A komlógyertyán (Ostrya carpinifolia) potenciális (bal) és prognosztikus (2041-2070) (jobb) elterjedése (0 - 0\% valószínüség, 1 - 100\% valószínűség) a „Maximum Entropy” módszer szerint végzett modellezés és RCP 4,5 forgatókönyv alapján.

Figure 3: Potential area of Ostrya carpinifolia for present (left) and future (2041-2070) (right)

(0 - 0\% feasibility, 1 - 100\% feasibility) using „Maximum Entropy” method and RCP 4,5 scenario.

Az előző fajoknál távolabbi természetes elterjedési területtel rendelkező magyaltölgy potenciális elterjedését is vizsgáltuk. Az eredmények visszaigazolták a növényi tulajdonságok komplex értékelése során alkalmazott szürési módszert. A fafaj egyik eljárás szerint sem bizonyult javasolhatónak hazánkban (4. ábra).
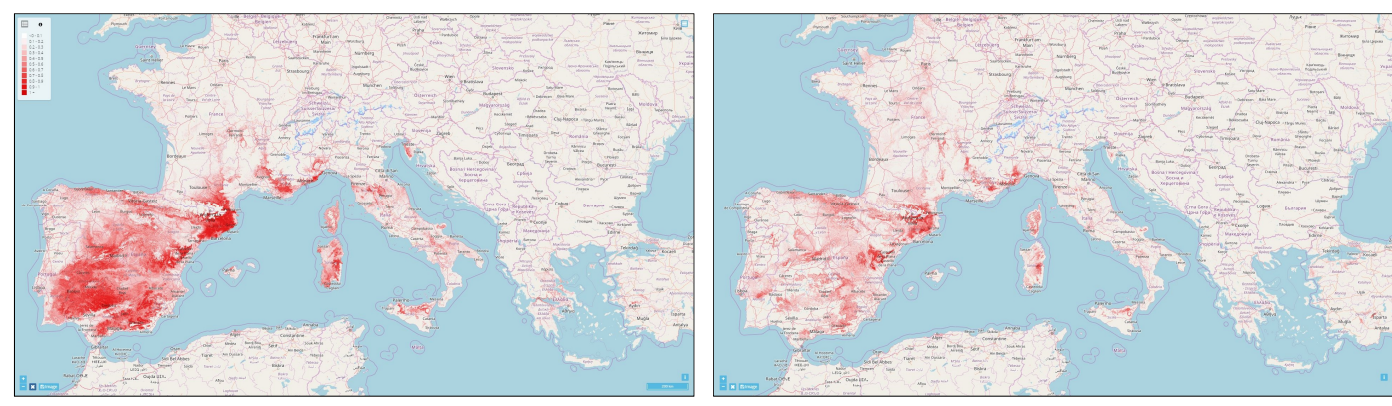

4. ábra: A magyaltölgy (Quercus ilex) potenciális (bal) és prognosztikus (2041-2070) (jobb) elterjedése (0 - 0\% valószínüség, 1 - 100\% valószínüség) a „Maximum Entropy” módszer szerint végzett modellezés és RCP 4,5 forgatókönyv alapján.

Figure 4: Potential area of Quercus ilex for present (left) and future (2041-2070) (right)

(0 - 0\% feasibility, 1 - 100\% feasibility) using „Maximum Entropy” method and RCP 4,5 scenario.

\section{Fafajok potenciális elterjedési mintázatainak modellezése}

\section{Virágos kőris (Fraxinus ornus)}

A virágos kőris európai elterjedési területe Délkelet-Franciaországtól, Olaszországon át egészen a Balkán-félszigeten keresztül nyugat Törökországig terjed. Szubmediterrán elter- 
jedésű fajról révén szó a relatív hőigénye a szubmediterrán sibljak és sztyepp övének megfelelö 8-as értéket kapta a Borhidi-féle ökológiai indikátor értékek szerint. A relatív talajvíz és talajnedvesség indikátor számai szerint a szárazságtürő, alkalmilag üde termőhelyen is előforduló növényfajok csoportjába tartozik. A talajreakció relatív értékszámai alapján a mészkedvelő fajok közé sorolható. A relatív fényigény alapján a félárnyéknövényekhez tartozik a Borhidi-féle ökológiai indikátor értékek alapján (Borhidi 1993).

A faj öshonos elterjedési területe Magyarországon a hegy- és dombvidéki területeket foglalja magába. Az előfordulási kvadrátok több mint 95\%-a 150 m-nél nagyobb magassági középértéknél fordul elő, ezért alsó határnak ezt az értéket vettük. A délies kitettségü lejtöket preferálja, ami a kvadrátok magasságkülönbségek szerinti eloszlásánál is megfigyelhető. A kvadrátok 98\%-a 50 m-nél nagyobb magasságkülönbségnél fordul elő, így alsó határnak 50 m-es magasságkülönbséget vettünk, míg felső határ megállapítását nem tartottuk indokoltnak a faj esetében.

Az ökológiai indikátor értékek alapján, ahogy már fent említettük, a virágos kőris a mészkedvelő fajok közé tartozik. A talaj kémhatása és mésztartalma szerint az előfordulási kvadrátok 83\%-ban karbonátos talajon fordul elö. Összesen 52 olyan elöfordulási kvadrát van, ahol a karbonátos talajok aránya $0 \%$, itt nagyobb területarányban a gyengén savanyú talajok jelennek meg.

Az éves csapadékmennyiséget elemezve az előfordulási kvadrátok több mint 95\%-a 750 $\mathrm{mm}$ alatti éves csapadékmennyiségnél fordul elö. A fajnál a nyári hónapok átlagos csapadékmennyiségét is elemeztük, mint elterjedést korlátozó klimatikus paramétert, a nyári hónapok szárazabb körülményeit tolerálja, a kvadrátok 260 mm-es csapadékmennyiség alatt fordulnak elő, ezért ezt az értéket vettük felső határnak.

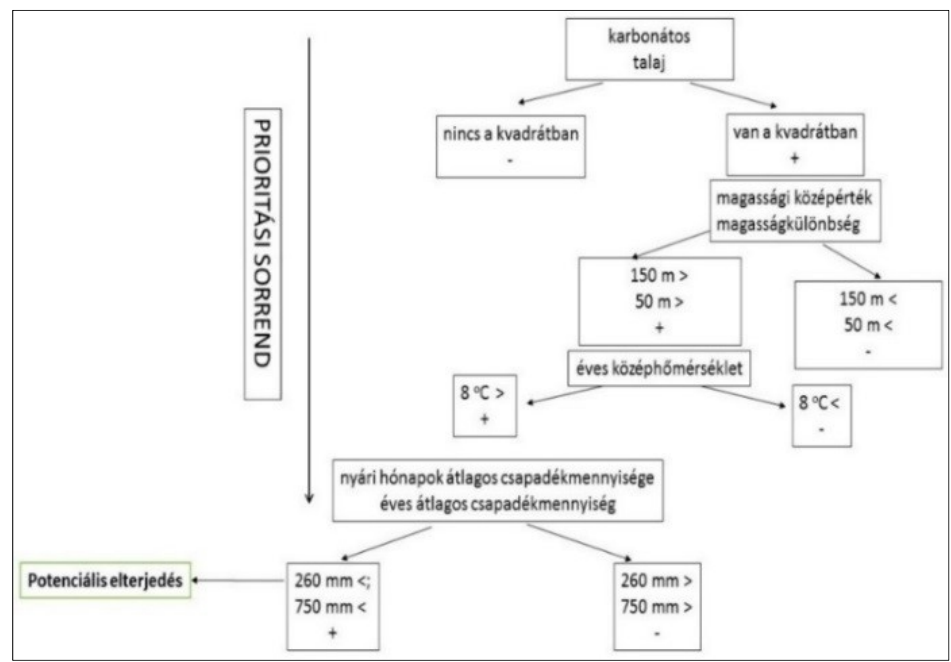

5. ábra: A virágos kőris (Fraxinus ornus) limitáló paraméterei és döntési fája.

Figure 5: Limit factors and decision tree of Fraxinus ornus. 
Az éves átlagos középhőmérsékletek alapján a kvadrátok $98 \%$-a 8 C-nál magasabb értéknél fordul elő. Szubmediterrán elterjedéséből adódóan alapvetően melegigényes faj, ezért feltételezhetően a magasabb éves átlagos középhőmérsékletet kedvező lesz a faj számára. Európai őshonos elterjedési területén $17-18{ }^{\circ} \mathrm{C}$-os értékeknél is megtalálható a faj (Caudullo \& De Rigo 2016). A téli hónapok átlagos hőmérséklet értékei a faj előfordulási kvadrátjaiban $-2{ }^{\circ} \mathrm{C}$ felett voltak, ezért alsó határként ezt az értéket vettük.

A nyári hónapok átlagos havi hőmérsékleti értékei szerint az előfordulási kvadrátok 98\%a $17^{\circ} \mathrm{C}$ feletti értékeknél jelenik meg (5. ábra).

A virágos kőris potenciális elterjedési térképe és az aktuális elterjedése között látható eltérés. Több kvadrát alkalmasnak mutatkozik számára az abiotikus háttértényezők és a beals smoothing módszer szerint, így a Sopron környéki Fertőmelléki-dombsor, az Északiközéphegységben az Aggteleki-karszt északkeleti pereme, a Heves-Borsodi-dombság, a Bükk-hegység és a Gödőllői-dombság. A faj jósolt előfordulását vizsgálva gyenge terjedés figyelhető meg, a szárazabb, melegebb klíma feltételezhetően kedvező hatással lesz a faj számára, így a hegy- és dombvidéki területeken a modell szerint megjelenhet (6. ábra).
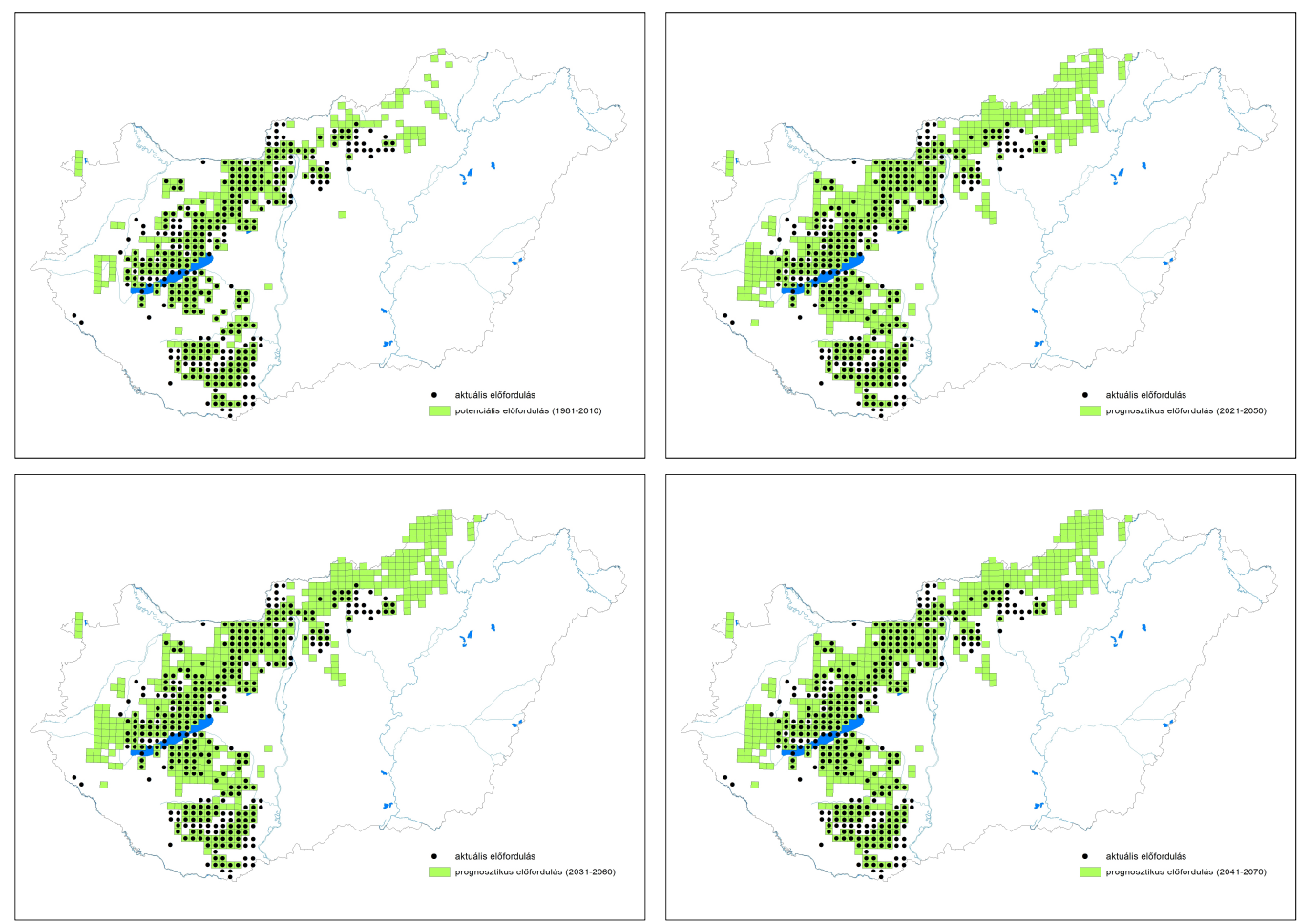

6. ábra: A virágos kőris (Fraxinus ornus) potenciális (•) és prognosztikus ( $\square$ ) előfordulása a klíma paraméterek és a „beals smoothing" elemzés alapján.

Figure 6: Potential ( $\bullet$ ) and prognostic ( $\square$ ) range of Fraxinus ornus according to climatic parameters and „beals smoothing” method. 


\section{Csertölgy (Quercus cerris)}

A csertölgy a keleti-szubmediterrán flóraelem kategóriába tartozik, az őshonos elterjedési területe Európa déli; délkeleti részére koncentrálódik. A Borhidi-féle relatív indikátor értékek alapján melegkedvelő $(T B=8)$, félüde termőhelyek $(W B=5)$ növényei közé sorolható. A relatív talajreakció alapján indifferens, széles türésü $(R B=6)$, a relatív fényigény szerint félárnyék, félnapfény ( $L B=6$ ) növények közé tartozik (Borhidi 1993).

Az elemzés során a faj őshonos előfordulási kvadrátjait vettük figyelembe, az erdészeti ültetések kiszürésre kerültek. A faj elterjedését és a magassági értékeit vizsgálva az elöfordulási kvadrátok több mint 80\%-a 150 m feletti magassági középértéknél fordul elő, ez az érték vehető alsó határnak. A magasságkülönbség értékei széles skálán oszlanak el, ezért erre a paraméterre nem állapítottunk meg limitáló értékeket.

A talaj mésztartalma és kémhatása szerint a faj előfordulási kvadrátjaiban erősen savanyú, karbonátos és gyengén savanyú talajok is jelen vannak. Mindösszesen öt elöfordulási kvadrátban volt jelen szikes talaj, ezért azon kvadrátokból, melyekben a szikes talajok aránya $100 \%$, a faj potenciális előfordulása kizárható, a csertölgy azonban megjelenhet erősen savanyú, gyengén savanyú és karbonátos talajon is.

A csertölgy aktuális elterjedési kvadrátjai szerint a faj több mint $90 \%$-a $8{ }^{\circ} \mathrm{C}$ feletti éves átlaghőmérsékleti értéknél fordul elő. A faj elterjedésénél figyelembe vettük a nyári és a téli hónapok átlaghőmérsékletét. A csertölgy melegigényes faj, így az elterjedését leginkább a téli hömérsékletek befolyásolhatják, hazánkban az előfordulási kvadrátok $97 \%$ - a $-1{ }^{\circ} \mathrm{C}$-nál magasabb téli átlagos hőmérsékleti értéknél fordul elő. A nyári átlagos hőmérsékleti értékek alapján $18{ }^{\circ} \mathrm{C}$ felett fordul elő a faj.

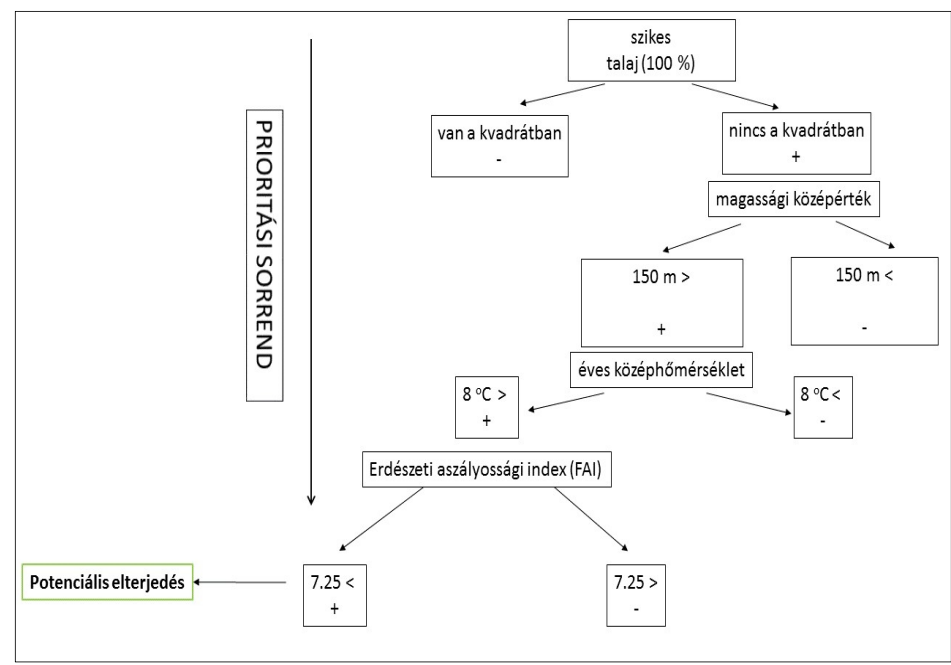

7. ábra: A csertölgy (Quercus cerris) limitáló paraméterei és döntési fája.

Figure 7: Limiting factors and decision tree of Quercus cerris. 
A csertölgy előfordulása és a nyári csapadékmennyiség között éles limitáló értéket nem állapítottunk meg, ugyanis feltételezhetően a hazánkban előforduló magasabb és alacsonyabb csapadékmennyiséget is képes tolerálni a faj.

Az erdészeti aszályossági index alapján a cseres-kocsánytalan tölgyes klíma 6.00-7.25 közötti értékeknél jelenik meg. A csertölgy azonban a gyertyános-tölgyes és bükkös klímában is jelen van, ami az előfordulási kvadrátok eloszlásában is megmutatkozik. Az erdészeti aszályossági index és az aktuális elterjedés kvadrátjainak eloszlása alapján 7.25-nél nagyobb értéknél az előfordulási kvadrátok száma csökken, ami a diagrammban is látható, ezért ezt állapítottuk meg felső limitáló értéknek (7. ábra).

A limitáló tényezők alapján megrajzoltuk a csertölgy potenciális elterjedési mintázatát és a jövőbeli prognosztikus elterjedést. A potenciális elterjedési nagyobb területet fed le a jelenlegi aktuális elterjedésnél, a Nyírségben és a Szigetköz északi részén mutatkozott eltérés. A klíma szcenáriók alapján a jövőben a csertölgy folyamatos visszaszorulása figyelhető meg, a Nyugat-Dunántúlon és az Északi-középhegységben lesznek jelen alkalmas klimatikus feltételek a faj számára (8. ábra).
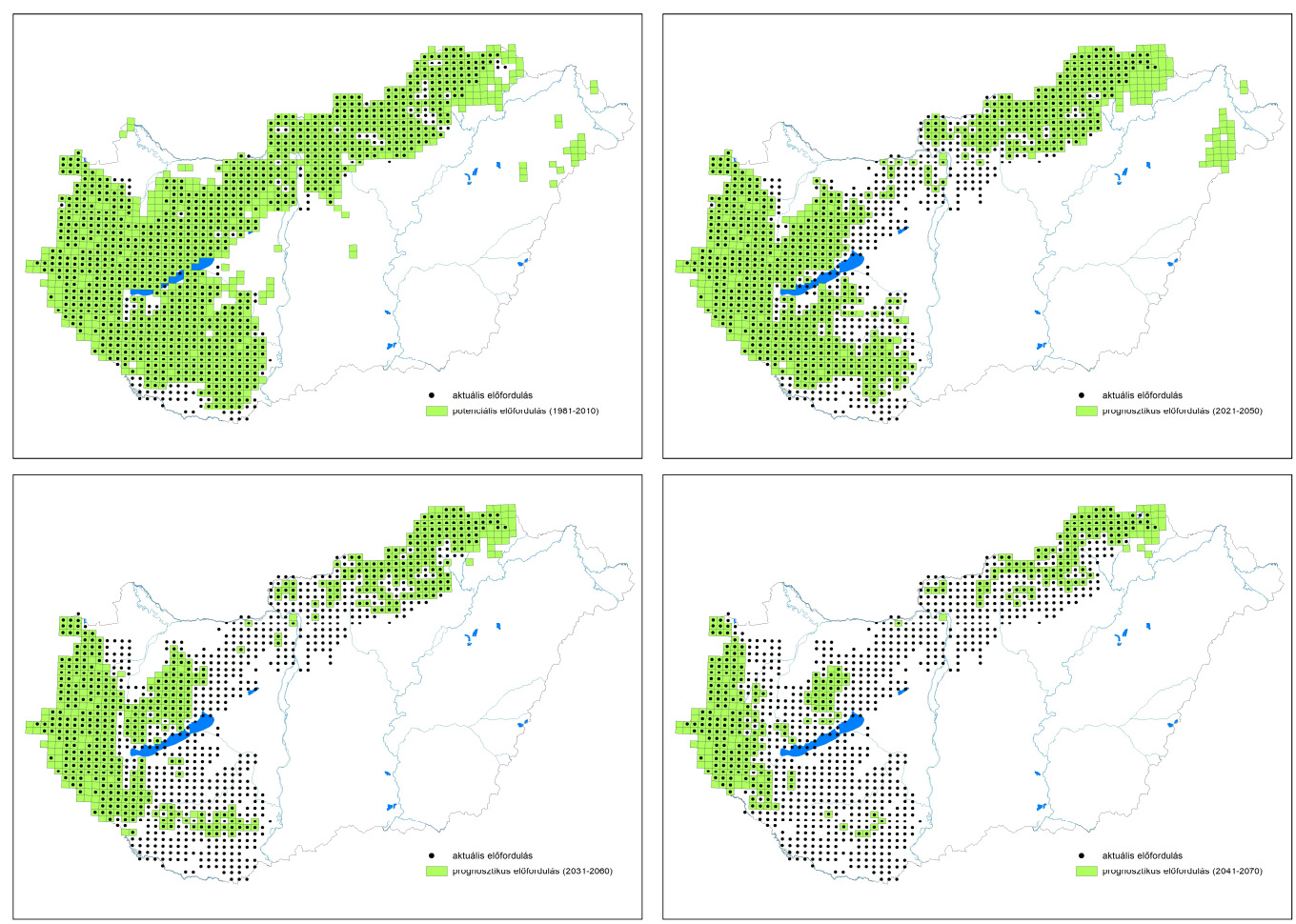

8. ábra: A csertölgy (Quercus cerris) potenciális (•) és prognosztikus ( $\square$ ) előfordulása a klíma paraméterek és a „beals smoothing” elemzés alapján.

Figure 8: Potential $(\bullet)$ and prognostic $(\square)$ range of Quercus cerris according to climatic parameters and „beals smoothing” method. 


\section{Nyugati ostorfa (Celtis occidentalis)}

A nyugati ostorfa Észak-Amerika keleti részében őshonos, leginkább síkvidékek fája (Bartha \& Csiszár 2012). Magyarországon terjedőben lévő inváziós fafajként tartjuk számon, mely leginkább a homokterületeken és ártereken jelenik meg. A faj tág tűrőképességgel rendelkezik, ami szintén elősegíti a térhódítását.

A talaj kémhatása és mésztartalma szempontjából minden típusban előfordul, ebből kifolyólag ez a környezeti tényező nem befolyásolja az elterjedését.

A faj síkvidéki jellegét a magyarországi elterjedése is jól tükrözi, az előfordulási kvadrátok mintegy 98\%-a 250 m alatti magassági középértékeknél jelenik meg. A faj elterjedésében a magasság limitáló faktorként van jelen, felső határként a $250 \mathrm{~m}$-t állapítottuk meg.

A klíma paraméterek közül vizsgáltuk a nyári hónapok átlagos és az éves átlagos csapadékmennyiséget, melyből kiderült, hogy a faj jól elviseli a nyári szárazságot is, így itt egy felső határt húztunk meg. A nyugati ostorfa elterjedési kvadrátjainak jelentős többsége 650 $\mathrm{mm}$ éves és $260 \mathrm{~mm}$ nyári átlagos csapadékmennyiség alatt fordul elő.

A hőmérséklet szempontjából a faj kiegyenlített hőigényü, az elterjedési kvadrátjai 8 ㄷ felett fordulnak elő hazánkban. Figyelembe vettük a klíma adatokból származtatott erdészeti aszályossági index értékeit is, melynél az alsó limitáló értéket 5.6-nál állapítottuk meg (9. ábra).

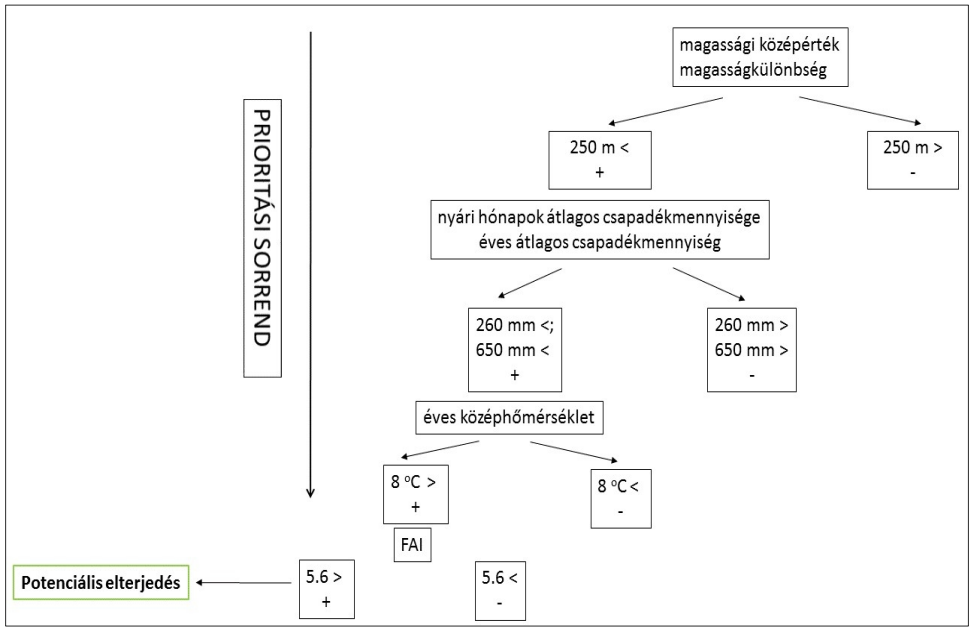

9. ábra: A nyugati ostorfa (Celtis occidentalis) limitáló paraméterei és döntési fája.

Figure 9: Limit factors and decision tree of Celtis occidentalis.

Előzetesen a nyugati ostorfa további terjedése jósolható hazánkban, melyet a klíma szcenáriók által számolt jövőbeli klíma paraméterek is alátámasztanak.

A faj potenciális elterjedési térképe alapján a nagyalföldi területek alkalmasak a klíma szempontjából a faj megjelenésére, így itt potenciálisan további terjedése várható. A jövőbeli 
prognosztikus elterjedés alapján megállapitható, hogy a hegylábi részeken és nyugati irányban várható a faj areájának növekedése. A jelenlegi elöfordulási területnél nagyobb mértékben fog előfordulni a faj, a klímaváltozás feltételezhetően kedvező lesz a faj számára (10. ábra).
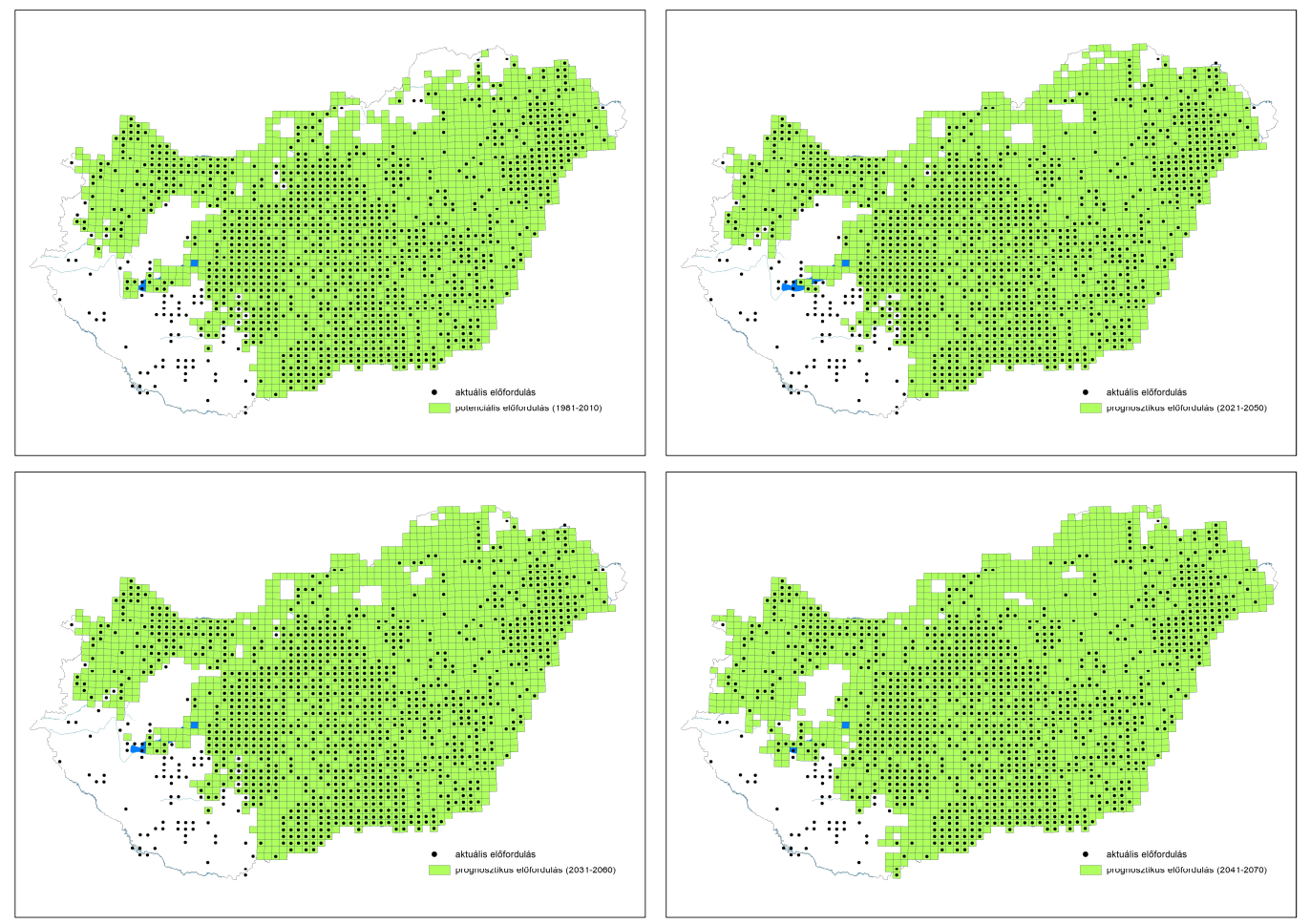

10. ábra: A nyugati ostorfa (Celtis occidentalis) potenciális (•) és prognosztikus ( $\square$ ) elöfordulása a klima paraméterek és a „beals smoothing” elemzés alapján.

Figure 10: Potential $(\bullet)$ and prognostic $(\square)$ range of Celtis occidentalis according to climatic parameters and „beals smoothing" method.

\section{Potenciális természetes erdőtársulások változásának becslése}

Jelentős átrendeződések várhatók a 2041-2070-es klímaperiódusig azoknál a potenciális erdőtársulás-csoportoknál, melyek a hegy- és dombvidéki klímaregionális társulások átalakulási sorához kapcsolódnak. Csak a potenciális bükkösök tizedrésze $(9,6 \%)$ esetében van reális esély arra, hogy a bükkös jelleg a gyertyános-kocsánytalan tölgyesekkel keveredve megmaradjon az Északi-középhegységben és a Nyugat-magyarországi peremvidéken. $\mathrm{A}$ potenciális bükkösök többségének $(77,7 \%)$ helyén várhatóan potenciális gyertyános-kocsánytalan tölgyeseknek megfelelő termőhelyi feltételek várhatók. A társuláscsoport termöhelyeinek 12,7\%-a esetében, a Dunántúli-középhegység és Dunántúli-dombság keleti részén, valamint a Mecsekben az előző eseteket is meghaladó átalakulás várható, mely az 
alkalmazott kategóriarendszerben a gyertyános-kocsánytalan tölgyes és a cseres-kocsánytalan tölgyes közé helyezhető.

A potenciális gyertyános-kocsánytalan tölgyesek átalakulásának spektruma viszonylag széles; a cseres-kocsánytalan tölgyesekkel alkotott átmeneti kategóriától $(3,2 \%)$ a mész- és melegkedvelő tölgyes - bokorerdő átmenetig $(3,2 \%)$ terjed. A társuláscsoport potenciális termőhelyei közel hasonló arányban alakulnak potenciális cseres-kocsánytalan tölgyes (28,8\%), mész- és melegkedvelő tölgyes (28,9\%), valamint az előző két kategória hibridjének megfelelő $(35,9 \%)$ termőhelyekké. A gyertyános-kocsánytalan tölgyesek eltérő átalakulási típusai földrajzilag a bükkösökhöz hasonló módon oszlanak el, kirajzolva az erdészeti aszályossági index (FAl) növekedésének mintázatát.

A jelenlegi potenciális cseres-kocsánytalan tölgyesek csaknem teljes területe várhatóan bokorerdőhöz hasonló potenciális vegetációval jellemezhető a 2041-2070 közötti időszakban. Erdőgazdálkodási szempontból pozitívnak tekinthető, hogy eredményeink szerint ezeken a termőhelyeken várhatóan biztosítható az erdőboritás fenntartása, alkalmazkodva a bokorerdőkre jellemző nyíltabb erdőszerkezethez.

A mész- és melegkedvelö tölgyeseknek megfelelö termöhelyek kevesebb, mint felén $(46,9 \%)$ prognosztizálható potenciális bokorerdő, többségük alkalmatlan lesz az erdők számára $(53,1 \%)$, hasonlóan, mint a jelenleg potenciális bokorerdők csaknem teljes területe (2. táblázat 11-12. ábra).

2. táblázat: $A$ hegy- és dombvidéki klímaregionális (és hozzájuk kapcsolódó) potenciális természetes erdőtársulás-csoportok becsült átalakulásának területarányai (\%) 1981-2010 és 2041-2070 között.

Table 2: Estimated conversation ratio (\%) of climate determined (and related) potential natural forest communities (colline and montane regions).

\begin{tabular}{|c|c|c|c|c|c|c|c|c|c|c|}
\hline \multirow{2}{*}{\multicolumn{2}{|c|}{$\begin{array}{l}\text { Aktuális potenciális természetes } \\
\text { erdőtársulás (PTE) }\end{array}$}} & \multicolumn{9}{|c|}{ Jövőbeli (2041-2070) potenciális természetes erdőtársulás (PTE) } \\
\hline & & $\begin{array}{l}\text { ×ヒ } \\
\text { 品 }\end{array}$ & $\frac{\text { E }}{\text { 交 }}$ & 扂卡 & $\frac{\text { E }}{\text { Sं }}$ & 乩备 & 这 & 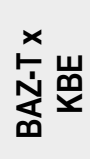 & 岗 & $\begin{array}{l}\text { :은 중 } \\
\text { 을 } \\
\text { 통 }\end{array}$ \\
\hline \multicolumn{2}{|c|}{ PTE kategóriák területaránya (\%) } & 0,721 & 5,857 & 1,772 & 7,605 & 9,085 & 7,317 & 0,859 & 14,959 & 16,424 \\
\hline $\begin{array}{l}\text { Bükkösök } \\
\text { (HDB) }\end{array}$ & 7,516 & 9,6 & 77,7 & 12,7 & 0 & 0 & 0 & 0 & 0 & 0 \\
\hline $\begin{array}{l}\text { Gyertyános-kocsánytalan } \\
\text { tölgyesek (GY-KTT) }\end{array}$ & 25,339 & 0 & 0 & 3,2 & 28,8 & 35,9 & 28,9 & 3,2 & 0 & 0 \\
\hline $\begin{array}{l}\text { Cseres-kocsánytalan } \\
\text { tölgyesek (CS-KTT) }\end{array}$ & 12,992 & 0 & 0 & 0 & 0 & 0 & 0 & 0,3 & 99,7 & 0 \\
\hline $\begin{array}{l}\text { Mész- és melegkedvelő } \\
\text { tölgyesek (BAZ-T) }\end{array}$ & 3,178 & 0 & 0 & 0 & 0 & 0 & 0 & 0 & 46,9 & 53,1 \\
\hline $\begin{array}{l}\text { Bokorerdők } \\
\text { (KBE) }\end{array}$ & 0,528 & 0 & 0 & 0 & 0 & 0 & 0 & 0 & 5,0 & 95,0 \\
\hline
\end{tabular}




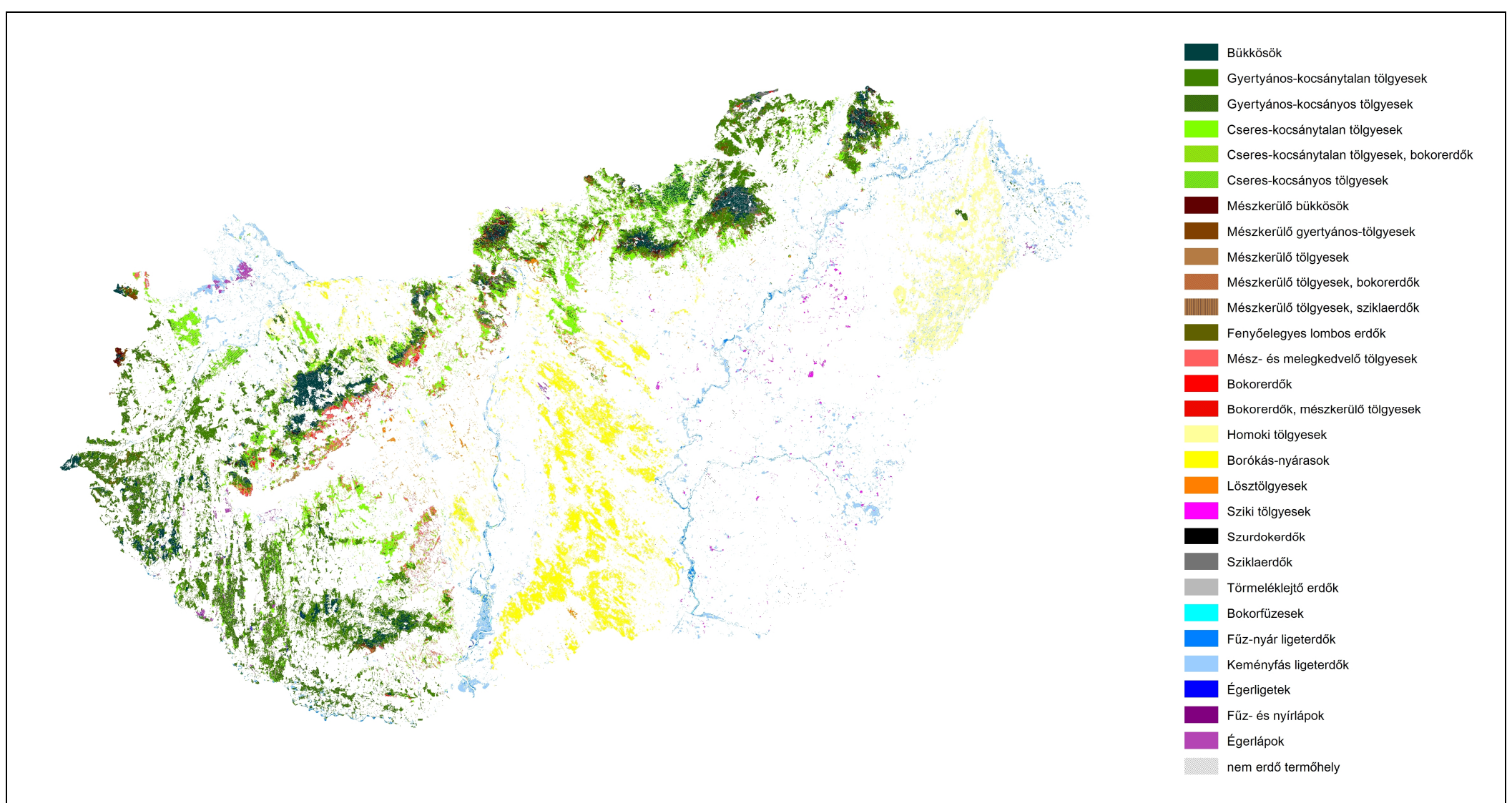

11. ábra: A potenciális természetes erdőtársulások (PTE) elterjedése Magyarországon. Figure 11: Distribution of potential natural forest communities in Hungary. 


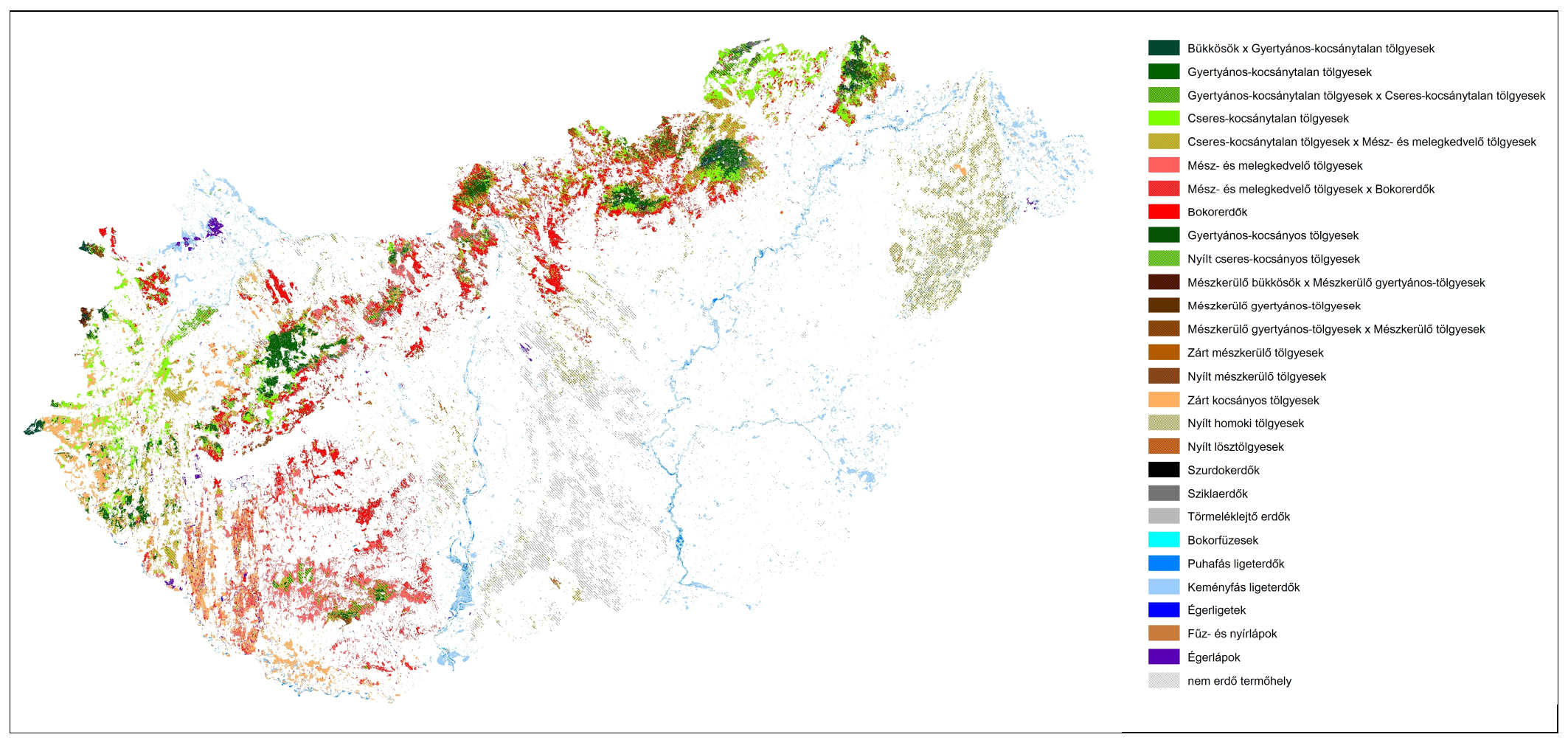

12. ábra: A potenciális természetes erdőtársulások (PTE) becsült elterjedése Magyarországon a klímaparaméterek elörevetített (2041-2070) változása alapján.

Figure 12: Estimeted distribution of potential natural forest communities according to climate change projections (2041-2070). 
A potenciális mészkerülő erdők becsült átalakulását összehasonlítva a párhuzamos klímaregionális erdők becsült átalakulásával látható, hogy mérsékeltebb a változás mértéke. A különbség oka, hogy a mészkerülő erdők olyan tájakra jellemzőek, ahol a kialakulásukat is befolyásoló csapadékmennyiség magasabb és a klímaváltozás hatásai is mérsékeltebben érvényesülnek. Bár a potenciális mészkerülő bükkösök többsége (69,2\%) átalakul mészkerülő gyertyános-tölgyessé, valamint a jelenlegi potenciális mészkerülő gyertyános-tölgyesek nagy része zárt mészkerülő tölgyessé válik, mindkét esetben több mint $20 \%$ azoknak a területeknek az aránya, melyek még az átalakulási sorban megelőző hibrid kategóriába sorolhatók a jövőben. A potenciális mészkerülö tölgyesek esetében várhatóan elsősorban szerkezeti változásokra kell számítani, a szárazodó termőhelyeknek nyilt mészkerülö tölgyesek feleltethetők meg. A mészkerülö tölgyesek kompozícionális rugalmasságát a társulás viszonylagos fajszegénysége jelentősen hátráltatja (3. táblázat).

A mészkerülő erdők dinamikáját a mindenkori tájhasználati folyamatok jelentősen befolyásolják. Az állományok jelentős részénél az aktuális tendencia a mészkerülő jelleg csökkenését és a klímaregionális jelleg erősödését jelenti. A mészkerülő erdők esetében a jövőbeli tájhasználat ismeretének hiányában ezzel a tényezővel az átalakulási folyamatok becslésénél nem számoltunk. A fenyőelegyes lombos erdők esetében figyelembe vettük az erdeifenyő visszaszorulásának folyamatát, így a kategória a jövőre vonatkozó PTE térképen már nem jelenik meg.

3. táblázat: A potenciális mészkerülő erdőtársulás-csoportok becsült átalakulásának területarányai (\%) 1981-2010 és 2041-2070 között.

Table 3: Estimated conversation ratio (\%) of potential acidofrequent natural forest communities between 1981-2010 and 2041-2070.

\begin{tabular}{|l|c|c|c|c|c|c|}
\hline \multirow{2}{*}{\begin{tabular}{l} 
Aktuális potenciális természetes \\
\multicolumn{1}{|c|}{ erdőtársulás (PTE) }
\end{tabular}} & \multicolumn{5}{|c|}{$\begin{array}{c}\text { Jövöbeli (2041-2070) potenciális természetes } \\
\text { erdötársulás (PTE) }\end{array}$} \\
\cline { 2 - 7 } & $\begin{array}{c}\text { AC-B x } \\
\text { AC-GY-T }\end{array}$ & AC-GY-T & $\begin{array}{c}\text { AC-GY-T x } \\
\text { AC-KTT }\end{array}$ & $\begin{array}{c}\text { zárt } \\
\text { AC-KTT }\end{array}$ & $\begin{array}{c}\text { nyilt } \\
\text { AC-KTT }\end{array}$ \\
\hline \multicolumn{2}{|l|}{ PTE kategóriák területaránya (\%) } & 0,141 & 0,365 & 0,286 & 0,944 & 0,652 \\
\hline $\begin{array}{l}\text { Mészkerülő bükkösök } \\
\text { (AC-B) }\end{array}$ & 0,528 & 26,8 & 69,2 & 4,0 & 0 & 0 \\
\hline $\begin{array}{l}\text { Mészkerülő } \\
\text { gyertyános-kocsánytalan } \\
\text { tölgyesek (AC-GY-T) }\end{array}$ & 1,185 & 0 & 0 & 22,3 & 77,7 & 0,0 \\
\hline $\begin{array}{l}\text { Mészkerülő tölgyesek } \\
\text { (AC-KTT) }\end{array}$ & 0,383 & 0 & 0 & 0 & 3,4 & 96,6 \\
\hline
\end{tabular}


Az erdőssztyep erdök közül a potenciális sziki tölgyesek várhatóan átadják helyüket a potenciális fátlan vegetációnak, szikes gyepeknek. Hasonló teljes átrendeződés jósolható a borókás-nyárasok viszonylatában. A lösztölgyesek és homoki tölgyesek területeinek nagy része felnyíló szerkezettel potenciális erdő-gyep vegetációkomplexet alkot a jövőben, kisebb hányaduk „nem erdő termőhellyé” válik majd (4. táblázat).

4. táblázat: $A$ potenciális erdőssztyep erdőtársulás-csoportok becsült átalakulásának területarányai (\%) 1981-2010 és 2041-2070 között.

Table 4: Estimated conversation ratio (\%) of potential forest-steppe communities between 1981-2010 and 2041-2070.

\begin{tabular}{|l|c|c|c|c|}
\hline \multirow{2}{*}{\begin{tabular}{|} 
Aktuális potenciális természetes \\
\multicolumn{2}{|c|}{ erdötársulás (PTE) }
\end{tabular}} & \multicolumn{3}{|c|}{$\begin{array}{c}\text { Jövöbeli (2041-2070) potenciális természetes } \\
\text { erdötársulás (PTE) }\end{array}$} \\
\cline { 2 - 5 } & $\begin{array}{c}\text { nyílt } \\
\text { LÖ-KST }\end{array}$ & $\begin{array}{c}\text { nyílt } \\
\text { HO-KST }\end{array}$ & $\begin{array}{c}\text { nem erdö } \\
\text { termöhely }\end{array}$ \\
\hline \multicolumn{2}{|l}{ PTE kategóriák területaránya (\%) } & 0,642 & 9,568 & 16,345 \\
\hline $\begin{array}{l}\text { Lösztölgyesek } \\
\text { (LÖ-KST) }\end{array}$ & 0,868 & 73,9 & 0 & 26,1 \\
\hline $\begin{array}{l}\text { Sziki tölgyesek } \\
\text { (HO-KST) }\end{array}$ & 0,493 & 0 & 0 & 100,0 \\
\hline $\begin{array}{l}\text { Homoki tölgyesek } \\
\text { (HO-KST) }\end{array}$ & 11,071 & 0 & 86,4 & 13,6 \\
\hline $\begin{array}{l}\text { Borókás-nyárasok } \\
\text { (BO-NY) }\end{array}$ & 11,265 & 0 & 0 & 100,0 \\
\hline
\end{tabular}

A potenciális gyertyános-kocsányos tölgyesek és a cseres-kocsányos tölgyesek jövőjére vonatkozóan az előző becsült átalakulási folyamatoknál is több bizonytalansággal kell számolnunk. A gyertyános-kocsányos tölgyes termőhelyek túlnyomó többsége $(98,3 \%)$ várhatóan „lép” egy klímaosztályt és a táji adottságoktól függően valamilyen potenciálisan zárt kocsányos tölgyes állomány képzelhető el rajta. Nagy valószínüséggel számos termőhelyen a jelenlegi kategóriarendszerbe nem illeszkedő, analógia nélküli erdőtípussal kell számolnunk. Cseres-kocsányos tölgyes termőhelyek esetében a jelenlegi potenciálisan zárt erdővegetáció felnyílása prognosztizálható.

Az alkalmazott potenciális természetes erdőtársulás (PTE) kategóriák egy részénél nem változtattunk a jelenlegi besoroláson a jövőre vonatkozóan sem. A ligeterdők és láperdők esetében a többletvízhatás változásának nehéz modellezhetősége nem tesz lehetővé megalapozott becslést. Ott, ahol megmarad a többletvíz, a potenciális vegetáció akár változatlan is maradhat, ha eltünik, akkor drasztikus változás várható. A sziklaerdők, szurdokerdők, tör- 
meléklejtő-erdők esetében a domborzatból adódó edafikus tényező a jövőben is meghatározó lesz, így a PTE kategória a jövőben is helytálló, valamilyen mértékben átalakuló fajkészlettel (5. táblázat).

5. táblázat: A modellezés során állandónak tekintett edafikus potenciális természetes erdőtársulások területe (ha, \%).

Table 5: Area (ha, \%) of "constant" defined potential natural forest community categories.

\begin{tabular}{|l|r|r|}
\hline \multirow{2}{*}{ Potenciális természetes erdőtársulás } & \multicolumn{2}{|c|}{ Terület } \\
\cline { 2 - 3 } & \multicolumn{1}{|c|}{ ha } & \multicolumn{1}{|c|}{$\%$} \\
\hline Sziklaerdök & 2453 & 0,130 \\
\hline Szurdokerdők & 502 & 0,027 \\
\hline Törmeléklejtő erdők & 2603 & 0,138 \\
\hline Égerligetek & 5564 & 0,294 \\
\hline Keményfás ligeterdők & 186099 & 9,838 \\
\hline Puhafás ligeterdők & 21208 & 1,121 \\
\hline Bokorfüzesek & 581 & 0,031 \\
\hline Égerlápok & 18960 & 1,002 \\
\hline Füz- és nyírlápok & 92 & 0,005 \\
\hline
\end{tabular}

\section{ÖSSZEFOGLALÁS ÉS KÖVETKEZTETÉSEK}

Kutatásunk során a klímaváltozás erdőtársulásokra gyakorolt hatásainak becsléséhez sokrétű megközelítést, különböző módszereket alkalmaztunk. Honos fafajaink várható reakcióit adatbázisokból származó növényi tulajdonságok alapján számítottuk, erdőtársulás-csoportonként értékelve a jövőben visszaszoruló vagy előnyhöz jutó fafajokat. A társulásokat alkotó (elegy)fafajok eltérő ökológiai spektruma, türőképessége, kompetíciós képessége, ideális esetben, csaknem minden erdőtársulás-csoport esetében lehetőséget nyújthat a társuláscsoporton belüli alkalmazkodásra vagy szárazabb klímarégió fajkészlete felé történő rugalmas átmenet kialakulására/kialakítására. A föként száraz, határtermőhelyekre koncentráló terepi vizsgálatok újulat és mortalitás adatai jórészt megerősítették az elméleti alapokon nyugvó becsléseinket, és az elegyfafajok kiemelt szerepét a gyakorlatban is igazolták.

Az erdészszakma felöl érkező, valós igény olyan idegenhonos, potenciális cserefafajok keresése, melyek a változó klímában segítséget jelenthetnek. Erre az igényre reagálva, de a jövőbeli invázió megelőzésének elvét hangsúlyosan figyelembe véve értékeltük az európai fafajokat. Kiválasztott fafajok esetében aktuális európai klímaadatokon alapuló modellezést is végeztünk, melynek során meghatároztuk a fajok potenciális és prognosztikus elterjedését. A kiválasztott tájidegen fafajok alkalmazására, csak az új körülmények között is vitális, 
őshonos taxonok és az általuk alkotott (akár újszerü) társulások által nyújtott lehetőségek kimerülését követően kerülhet sor.

Kiválasztott honos és inváziós fafafajok esetében az országos flóratérképezési adatbázis és az elörevetített klímaadatok alapján becsültük fajok potenciális és prognosztikus elterjedését. A térképek erdőtársulásoktól függetlenül mutattak rá azokra a tájakra, melyekben az adott honos fafaj alkalmazása kétségessé vagy lehetségessé válhat, illetve ahol nő az inváziós veszélyeztetettség.

Potenciális természetes erdőtársulás (PTE) adatbázist építettünk fel az ország erdőterületeire a jelenre és jövőre vonatkozóan egyaránt, az Országos Erdőállomány Adattár adatai és az erdészeti aszályossági index ( $\mathrm{FAl}$ ) erdőrészletekhez rendelt értékeinek különbségei alapján. A jelenlegi potenciális bükkös termőhelyek erősen veszélyeztetettek. A száraz tölgyesek alkalmazkodóképességét növelheti potenciális elegyfafajaik magas száma, melyek jelentős része (pl. mezei juhar) tág türőképességü. A mész- és melegkedvelő tölgyesek, bokorerdők és az erdőssztyep tölgyesek átalakult formában való megmaradásához az állományok felnyílása (vagy mozaikos állományok létrehozása) nyújthat megoldást.

Összefoglalásként megállapítható, hogy a klimatikus változások erdeinkre gyakorolt eröteljes hatásai elkerülhetetlenek, de az erdők összetételi (elegyesség) és szerkezeti diverzitásának (pl. gyepekkel, cserjésekkel mozaikoló állományok) növelése, kiegészülve a természetes dinamika "használatával” (és az invázió megakadályozásával) számos kihasználatlan, az erdőgazdálkodás és a természetvédelem számára is előnyös alkalmazkodási lehetőséget rejt.

\section{KÖSZÖNETNYILVÁNÍTÁS}

A kutató munka a VKSZ_12-1-2013-0034 „Agrárklíma 2” projekt és a "Soproni Egyetem Struktúraváltási Terve" - 32388-2/2017 INTFIN sz. projekt keretében az Emberi Erőforrások Minisztériuma támogatásával valósult meg.

\section{FELHASZNÁLT IRODALOM}

Mauri A., Strona G. \& San-Miguel-Ayanz J. 2017: EU-Forest, a high-resolution tree occurrence dataset for Europe. Scientific Data 4: 160123. DOI: 10.1038/sdata.2016.123

Barcza Z., Bartholy J., Mészáros R., Pongrácz R. \& Radics K. 2011: Globális és európai tendenciák. In: Bartholy J., Bozó L. \& Haszpra J. (eds): KLÍMAVÁLTOZÁS - 2011 Klímaszcenáriók a Kárpát-medence térségére. Magyar Tudományos Akadémia és az Eötvös Loránd Tudományegyetem Meteorológiai Tanszéke, Budapest, 99-144.

Bartha D. 1999: Bewertung der Dendroflora Europas auf Grund der Lebensformen. Tilia 7(Suppl.): 3-30.

Bartha D., Bölöni J., Ódor P., Standovár T., Szmorad F. \& Tímár G. 2003: A magyarországi erdők természetességének vizsgálata. Erdészeti Lapok 138(3): 73-75.

Bartha D. 2005: Tájállapotok és vegetációállapotok, mint az erdőtermészetességi vizsgálatok viszonyítási alapjai. Tájökológiai Lapok 3(2): 253-274. 
Bartha D. 2012: Növényföldrajz és társulástan. Egyetemi jegyzet. Nyugat-magyarországi Egyetem Kiadó, Sopron.

Bartha D. \& Csiszár Á. 2012: Nyugati ostorfa (Celtis occidentalis L.). In: Csiszár Á. (ed): Inváziós növényfajok Magyarországon. Nyugat-magyarországi Egyetem Kiadó, Sopron, 109-113.

Bartha D., Korda M., Kovács G. \& Tímár G. 2014: A potenciális természetes erdőtársulások és az aktuális faállománytípusok összevetése országos szinten. Erdészettudományi Közlemények 4(1): 7-21.

Bartha D., Király G., Schmidt D., Tiborcz V., Barina Z., Csiky J., et al. (eds) 2015: Magyarország edényes növényfajainak elterjedési atlasza. Nyugat-magyarországi Egyetem Kiadó, Sopron.

Bartholy J., Bihari Z., Horányi A., Krüzselyi I., Lakatos M., Pieczka I., et al. 2011: Hazai éghajlati tendenciák. In: Bartholy J., Bozó L. \& Haszpra J. (eds). KLÍMAVÁLTOZÁS - 2011 Klímaszcenáriók a Kárpát-medence térségére. Magyar Tudományos Akadémia és az Eötvös Loránd Tudományegyetem Meteorológiai Tanszéke, Budapest, 145-234.

Berki I., Móricz N., Rasztovits E. \& Vig P. 2007: A bükk szárazság tolerancia határának meghatározása. In: Mátyás Cs. \& Vig P. (eds): Erdő és klíma V. Nyugat-Magyarországi Egyetem, Sopron, 213-228.

Borhidi A.1993: A Magyar Flóra szociális magatartás típusai, természetességi és relatív ökológiai értékszámai. Janus Pannonius Tudományegyetem, Pécs.

Caudullo G. \& de Rigo D. 2016: Fraxinus ornus in Europe: distribution, habitat, usage and threats. In: SanMiguel-Ayanz J., de Rigo D., Caudullo G., Houston Durran T. \& Mauri A. (eds): European Atlas of Forest Tree Species. The Publications Office of the European Union, Luxembourg, 100-101.

De Cáceres M. \& Legendre P. 2008: Beals smoothing revisited. Oecologia 156(3): 657-669. DOI: 10.1007/s00442-008-1017-y

Führer E. 2010: A fák növekedése és a klíma. Klíma-21 Füzetek 61: 98-107.

Hamann A., Wang T., Spittlehouse D.L. \& Murdock T.Q. 2013: A comprehensive, high-resolution database of historical and projected climate surfaces for western North America. Bulletin of the American Meteorological Society 94: 1307-1309. DOI: 10.1175/bams-d-12-00145.1

Hoegh-Guldberg O., Hughes L., Mclntyre S., Lindenmayer D.B., Parmesan C., Possingham H.P., et al. 2008: Assisted colonization and rapid climate change. Science 321(5887): 345-346. DOI: 10.1126/science.1157897

Somodi I., Molnár Zs., Czúcz B., Bede-Fazekas Á., Bölöni J., Pásztor L., et al. 2017: Implementation and application of Multiple Potential Natural Vegetation models - a case study of Hungary. Journal of Vegetation Science 28(6): 1260-1269. DOI: 10.1111/jvs.12564

Király G. \& Horváth F. 2000: Magyarország flórájának térképezése: lehetőségek a térképezés hálórendszerének megválasztására. Kitaibelia 5(2): 357-368.

Király G. 2003: A magyarországi flóratérképezés módszertani alapjai. Flora Pannonica 1(1): 3-20.

Kotroczó Zs., Krakomperger Zs., Papp M., Bowden R.D. \& Tóth J.A. 2007: A Síkfőkúti cseres-kocsánytalan tölgyes szerkezetének és fajösszetételének hosszútávú változása. Természetvédelmi Közlemények 13: 93-100.

McLachlan J.S., Hellmann J.J. \& Schwartz M.W. 2007: A framework for debate of assisted migration in an era of climate change. Conservation Biology 21: 297-302. DOI: 10.1111/j.1523-1739.2007.00676.x

Mátyás Cs. 2009: Ecological challenges of climate change in Europe's continental, drought- threatened Southeast. In: Groisman P.Y., Ivanov S.V. (eds): Regional Aspects of Climate-Terrestrial-Hydrologic Interactions in Non-boreal Eastern Europe. NATO Science for Peace and Security Series C: Environmental Security. Springer, Dordrecht, 35-46. DOI: 10.1007/978-90-481-2283-7_5

Mátyás Cs., Führer E., Berki I., Csóka Gy., Drüszler Á., Lakatos F., et al. 2010: Erdők a szárazsági határon. Klíma-21 Füzetek 61: 84-97.

Molnár Cs., Molnár Zs., Barina Z., Bauer N., Biró M., Bodonczi L., et al. 2008: Vegetation-based landscaperegions of Hungary. Acta Botanica Hungarica 50(Suppl.): 47-58.

Molnár M. \& Lakatos F. 2007: A bükkpusztulás Zala-megyében - klímaváltozás? In: Mátyás Cs. \& Vig P. (eds): Erdő és klíma V. Nyugat-Magyarországi Egyetem, Sopron, 257-267. 
Niklfeld H.1971: Bericht über die Kartierung der Flora Mitteleuropas. Taxon 20: 545-571. DOl: $10.2307 / 1218258$

Richardson D.M., Hellmann J.J., McLachlan J.S., Sax D.F., Schwartz M.W., Gonzalez P., et al. 2009: Multidimensional evaluation of managed relocation. Proceedings of the National Academy of Sciences of the United States of America 106: 9721-9724. DOI: 10.1073/pnas.0902327106

Roloff A. \& Bärtels A. 2006: Flora der Gehölze. Ulmer Verlag, Stuttgart.

Schwartz M.W. 2012: Using niche models with climate projections to inform conservation management decisions. Biological Conservation 155:149-156. DOI: 10.1016/j.biocon.2012.06.011

Somogyi Z. 2007: A klíma, a klímaváltozás és a fanövedék néhány összefüggéséröl. In: Mátyás Cs. \& Vig P. (eds): Erdő és klíma V. Nyugat-Magyarországi Egyetem, Sopron, 295-306.

Standovár T., Bán M. \& Kézdy P. (eds) 2017: Erdőállapot-értékelés középhegységi erdeinkben. (Forest state assessment in submontane woodlands.) Duna-Ipoly Nemzeti Park Igazgatóság, Budapest.

\section{On-line irodalom}

URL1: Andreas Hamann's personal website / ClimateEU: historical and projected climate data for Europe. https://sites.ualberta.ca/ ahamann/data/climateeu.html (letöltve: 2018. 08. 01)

Érkezett: 2018. május 4.

Közlésre elfogadva: 2018. május 31. 